\title{
LEVEL II SCOUR ANALYSIS FOR BRIDGE 63 (CHESTH00090063) on TOWN HIGHWAY 9, crossing the WILLIAMS RIVER, CHESTER, VERMONT
}

U.S. Geological Survey Open-File Report 97-423

Prepared in cooperation with

VERMONT AGENCY OF TRANSPORTATION and

FEDERAL HIGHWAY ADMINISTRATION 


\section{LEVEL II SCOUR ANALYSIS FOR BRIDGE 63 (CHESTH00090063) on TOWN HIGHWAY 9, crossing the WILLIAMS RIVER, CHESTER, VERMONT By ROBERT H. FLYNN}

U.S. Geological Survey Open-File Report 97-423

Prepared in cooperation with

VERMONT AGENCY OF TRANSPORTATION

and

FEDERAL HIGHWAY ADMINISTRATION 


\title{
U.S. DEPARTMENT OF THE INTERIOR BRUCE BABBITT, Secretary
}

\author{
U.S. GEOLOGICAL SURVEY \\ Gordon P. Eaton, Director
}

For additional information write to:

District Chief

U.S. Geological Survey 361 Commerce Way

Pembroke, NH 03275-3718
Copies of this report may be purchased from:

U.S. Geological Survey

Branch of Information Services

Open-File Reports Unit

Box 25286

Denver, CO 80225-0286 


\section{CONTENTS}

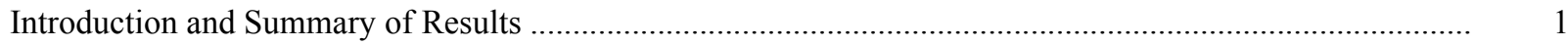

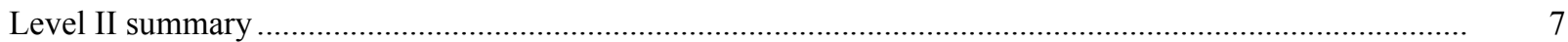

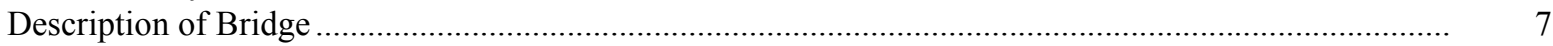

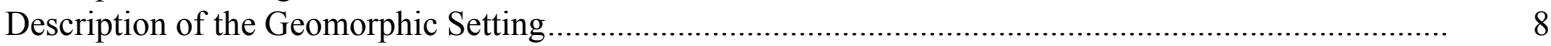

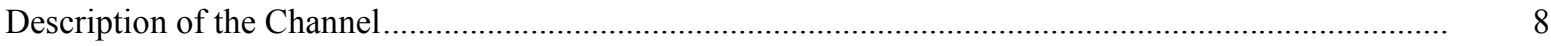

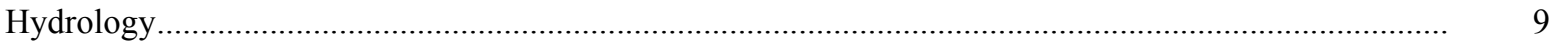

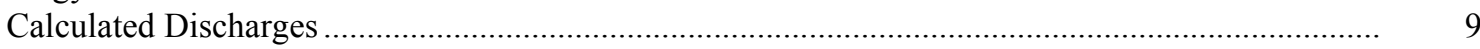

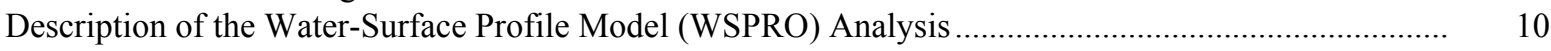

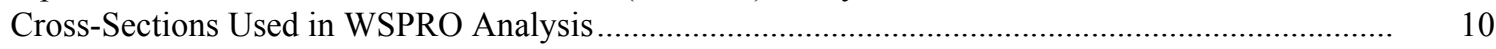

Data and Assumptions Used in WSPRO Model ...................................................................... 11

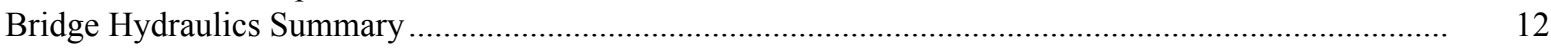

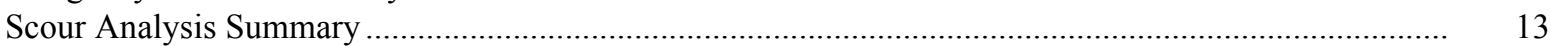

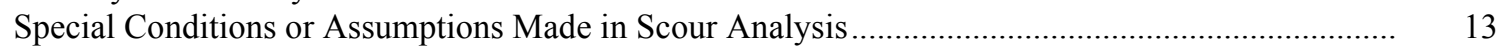

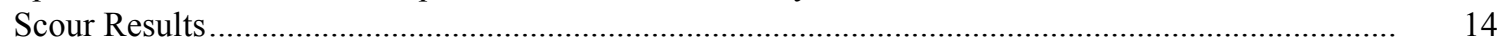

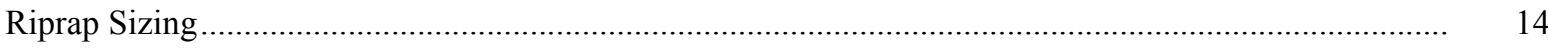

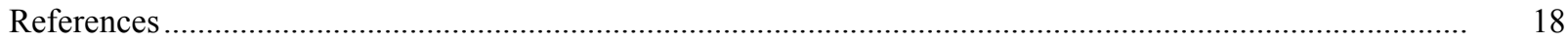

Appendixes:

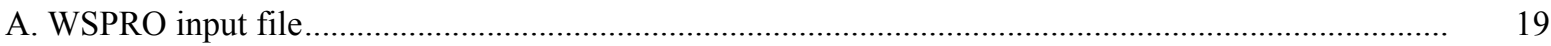

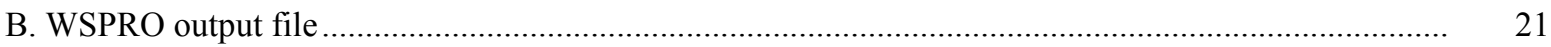

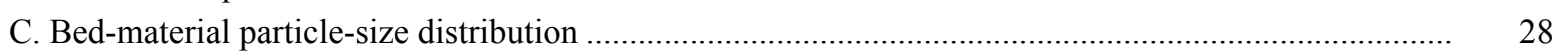

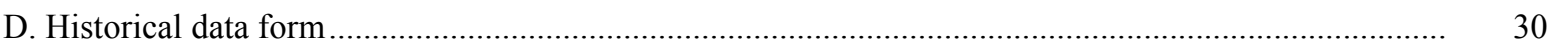

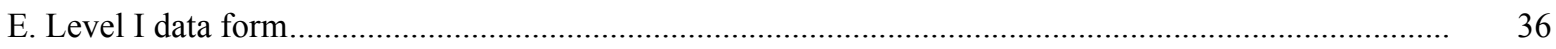

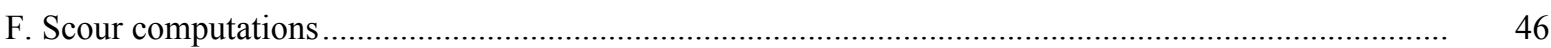

\section{FIGURES}

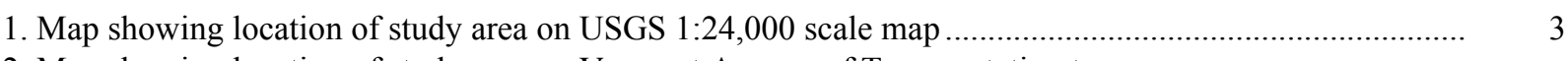

2. Map showing location of study area on Vermont Agency of Transportation town

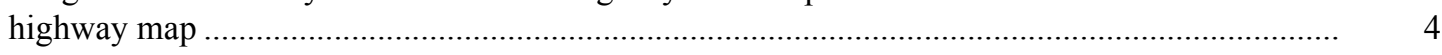

3. Structure CHESTH00090063 viewed from upstream (September 18, 1996) ........................................... 5

4. Downstream channel viewed from structure CHESTH00090063 (September 18, 1996)........................ 5

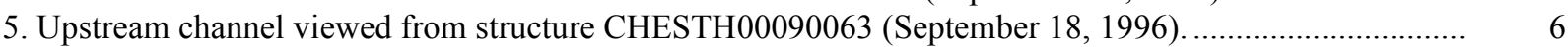

6. Structure CHESTH00090063 viewed from downstream (September 18, 1996).................................... 6

7. Water-surface profiles for the 100- and 500-year discharges at structure

CHESTH00090063 on Town Highway 9, crossing the Williams River,

Chester, Vermont.

8. Scour elevations for the 100- and 500-year discharges at structure

CHESTH00090063 on Town Highway 9, crossing the Williams River,

Chester, Vermont.

\section{TABLES}

1. Remaining footing/pile depth at abutments for the 100-year discharge at structure

CHESTH00090063 on Town Highway 9, crossing the Williams River,

Chester, Vermont

2. Remaining footing/pile depth at abutments for the 500-year discharge at structure

CHESTH00090063 on Town Highway 9, crossing the Williams River,

Chester, Vermont 


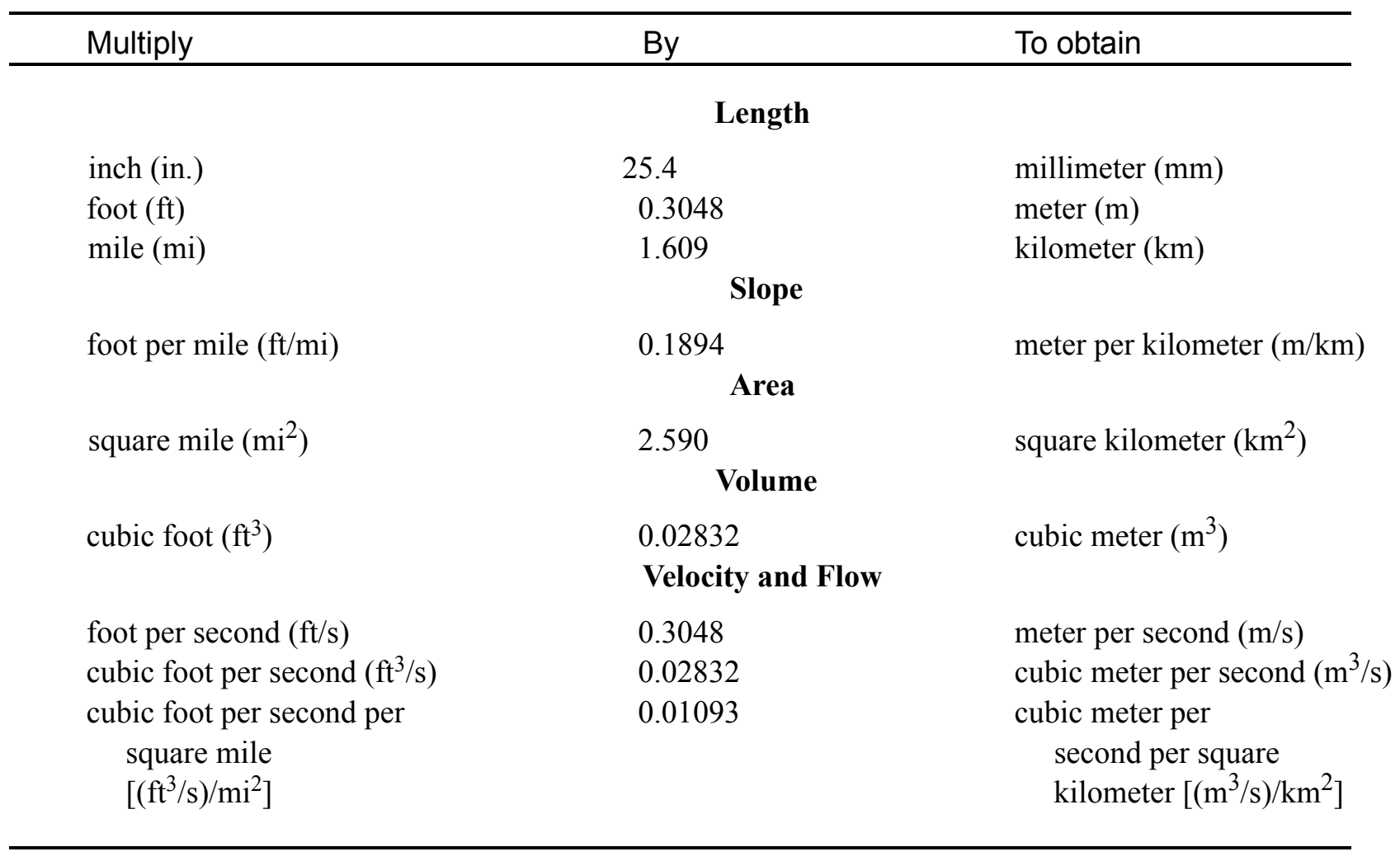

\section{OTHER ABBREVIATIONS}

$\begin{array}{lrlr}\mathrm{BF} & \text { bank full } & \text { LWW } & \text { left wingwall } \\ \mathrm{cfs} & \text { cubic feet per second } & \text { MC } & \text { main channel } \\ \mathrm{D}_{50} & \text { median diameter of bed material } & \text { RAB } & \text { right abutment } \\ \mathrm{DS} & \text { downstream } & \text { RABUT } & \text { face of right abutment } \\ \mathrm{elev} & \text { elevation } & \text { RB } & \text { right bank } \\ \mathrm{f} / \mathrm{p} & \text { flood plain } & \text { ROB } & \text { right overbank } \\ \mathrm{ft}^{2} & \text { square feet } & \text { RWW } & \text { right wingwall } \\ \mathrm{ft} / \mathrm{ft} & \text { feet per foot } & \text { TH } & \text { town highway } \\ \mathrm{JCT} & \text { junction } & \text { UB } & \text { under bridge } \\ \mathrm{LAB} & \text { left abutment } & \text { US } & \text { upstream } \\ \mathrm{LABUT} & \text { face of left abutment } & \text { USGS } & \text { United States Geological Survey } \\ \mathrm{LB} & \text { left bank } & \text { VTAOT Vermont Agency of Transportation } \\ \mathrm{LOB} & \text { left overbank } & \text { WSPRO } & \text { water-surface profile model }\end{array}$

In this report, the words "right" and "left" refer to directions that would be reported by an observer facing downstream. Sea level: In this report, "sea level" refers to the National Geodetic Vertical Datum of 1929-- a geodetic datum derived from a general adjustment of the first-order level nets of the United States and Canada, formerly called Sea Level Datum of 1929.

In the appendices, the above abbreviations may be combined. For example, USLB would represent upstream left bank. 


\title{
LEVEL II SCOUR ANALYSIS FOR BRIDGE 63 (CHESTH00090063) ON TOWN HIGHWAY 9, CROSSING THE WILLIAMS RIVER, CHESTER, VERMONT
}

\author{
By Robert H. Flynn
}

\section{INTRODUCTION AND SUMMARY OF RESULTS}

This report provides the results of a detailed Level II analysis of scour potential at structure CHESTH00090063 on Town Highway 9 crossing the Williams River, Chester, Vermont (figures 1-8). A Level II study is a basic engineering analysis of the site, including a quantitative analysis of stream stability and scour (U.S. Department of Transportation, 1993). Results of a Level I scour investigation also are included in Appendix E of this report. A Level I investigation provides a qualitative geomorphic characterization of the study site. Information on the bridge, gleaned from Vermont Agency of Transportation (VTAOT) files, was compiled prior to conducting Level I and Level II analyses and is found in Appendix D.

The site is in the New England Upland section of the New England physiographic province in eastern Vermont. The $24.0-\mathrm{mi}^{2}$ drainage area is in a predominantly rural and forested basin. In the vicinity of the study site, the surface cover is grass with trees and brush along the immediate banks.

In the study area, the the Williams River has an incised, sinuous channel with a slope of approximately $0.005 \mathrm{ft} / \mathrm{ft}$, an average channel top width of $64 \mathrm{ft}$ and an average bank height of $6 \mathrm{ft}$. The channel bed material ranges from gravel to boulder with a median grain size $\left(\mathrm{D}_{50}\right)$ of $57.7 \mathrm{~mm}(0.189 \mathrm{ft})$. The geomorphic assessment at the time of the Level I and Level II site visit on September 18, 1996, indicated that the reach was stable.

The Town Highway 9 crossing of the Williams River is a 45-ft-long, two-lane bridge consisting of one 35-foot steel-beam span with a timber deck (Vermont Agency of Transportation, written communication, April 6, 1995). The bridge is supported by vertical, concrete abutments with wingwalls. The channel is skewed approximately 5 degrees to the opening while the opening-skew-to-roadway is 0 degrees. 
A scour hole $1.8 \mathrm{ft}$ deeper than the mean thalweg depth was observed along the left abutment during the Level I assessment. The scour hole undermines the left abutment and extends from $50 \mathrm{ft}$ upstream of the upstream bridge face to $50 \mathrm{ft}$ downstream of the downstream bridge face. The scour protection measures at the site included type- 3 stone fill (less than 48 inches diameter) under the bridge along the entire base length of the right abutment and along the right bank from 50 to $88 \mathrm{ft}$ upstream. Type-2 (less than 36 inches diameter) stone fill scour protection was observed along the downstream left bank from 18 $\mathrm{ft}$ to $115 \mathrm{ft}$, along the downstream right bank from $8 \mathrm{ft}$ to $25 \mathrm{ft}$ and along the upstream left bank from 50 to $75 \mathrm{ft}$. Additional details describing conditions at the site are included in the Level II Summary and Appendices D and E.

Scour depths and recommended rock rip-rap sizes were computed using the general guidelines described in Hydraulic Engineering Circular 18 (Richardson and others, 1995). Total scour at a highway crossing is comprised of three components: 1) long-term streambed degradation; 2) contraction scour (due to accelerated flow caused by a reduction in flow area at a bridge) and; 3 ) local scour (caused by accelerated flow around piers and abutments). Total scour is the sum of the three components. Equations are available to compute depths for contraction and local scour and a summary of the results of these computations follows.

Contraction scour for all modelled flows was computed to be $0.0 \mathrm{ft}$. Abutment scour ranged from $10.1 \mathrm{ft}$ to $11.0 \mathrm{ft}$ along the left abutment and from $14.1 \mathrm{ft}$ to $15.1 \mathrm{ft}$ along the right abutment. The worst-case abutment scour for the left abutment occurred at the 500-year discharge while the worst-case abutment scour for the right abutment occurred at the 100year discharge. Additional information on scour depths and depths to armoring are included in the section titled "Scour Results". Scoured-streambed elevations, based on the calculated scour depths, are presented in tables 1 and 2. A cross-section of the scour computed at the bridge is presented in figure 8 . Scour depths were calculated assuming an infinite depth of erosive material and a homogeneous particle-size distribution.

It is generally accepted that the Froehlich equation (abutment scour) gives "excessively conservative estimates of scour depths" (Richardson and others, 1995, p. 47). Usually, computed scour depths are evaluated in combination with other information including (but not limited to) historical performance during flood events, the geomorphic stability assessment, existing scour protection measures, and the results of the hydraulic analyses. Therefore, scour depths adopted by VTAOT may differ from the computed values documented herein. 


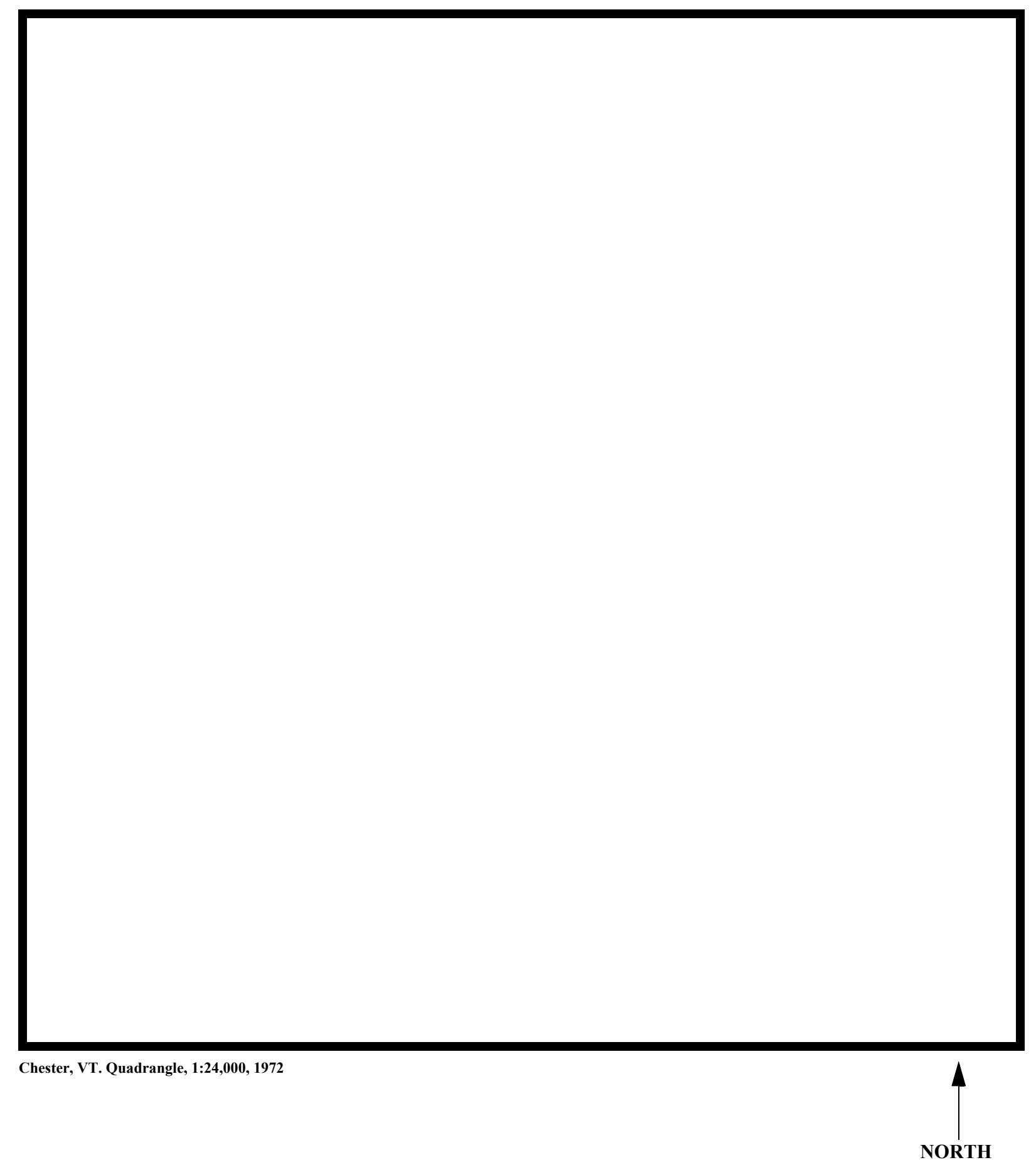

Figure 1. Location of study area on USGS 1:24,000 scale map. 
Figure 2. Location of study area on Vermont Agency of Transportation town highway map. 

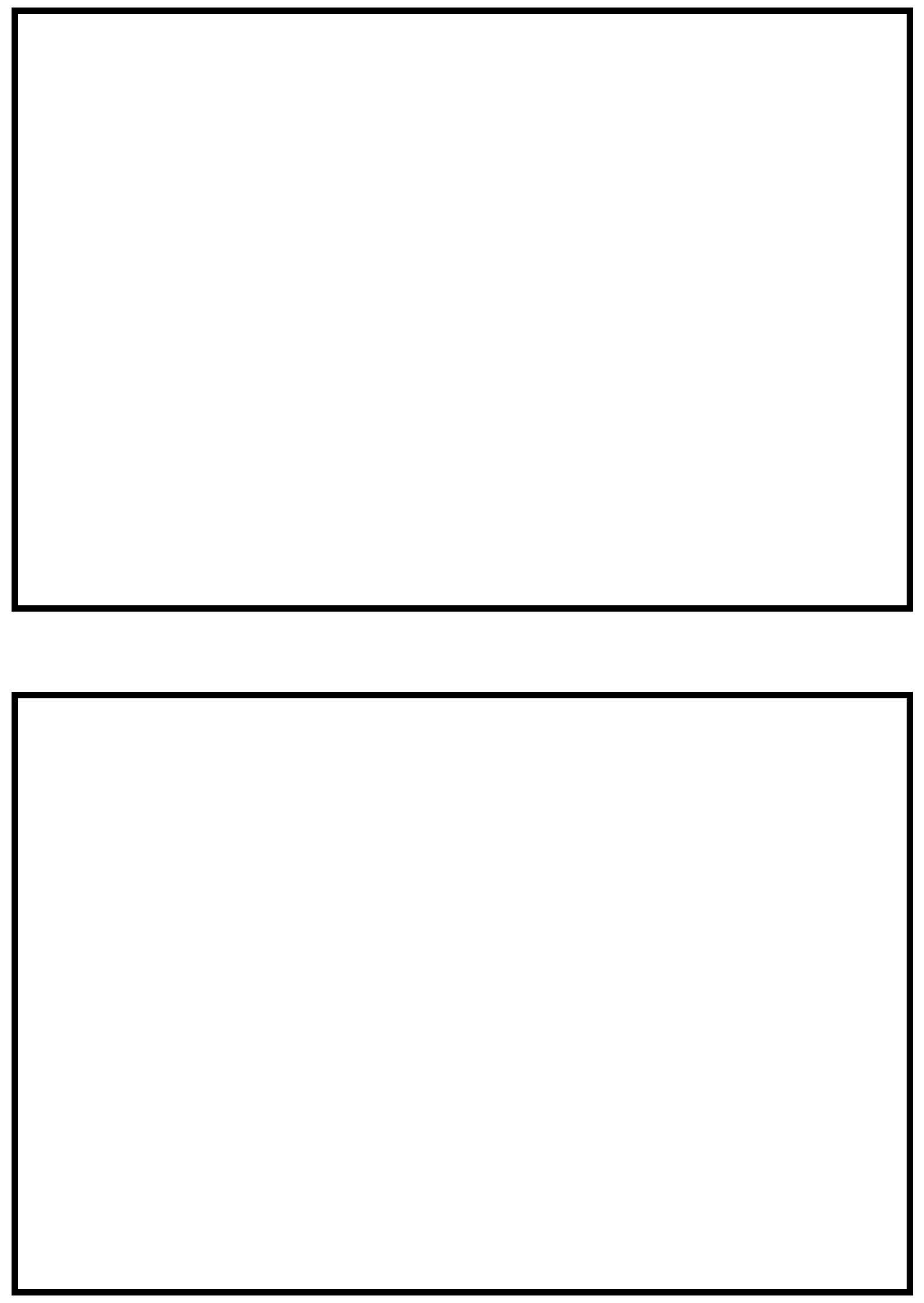

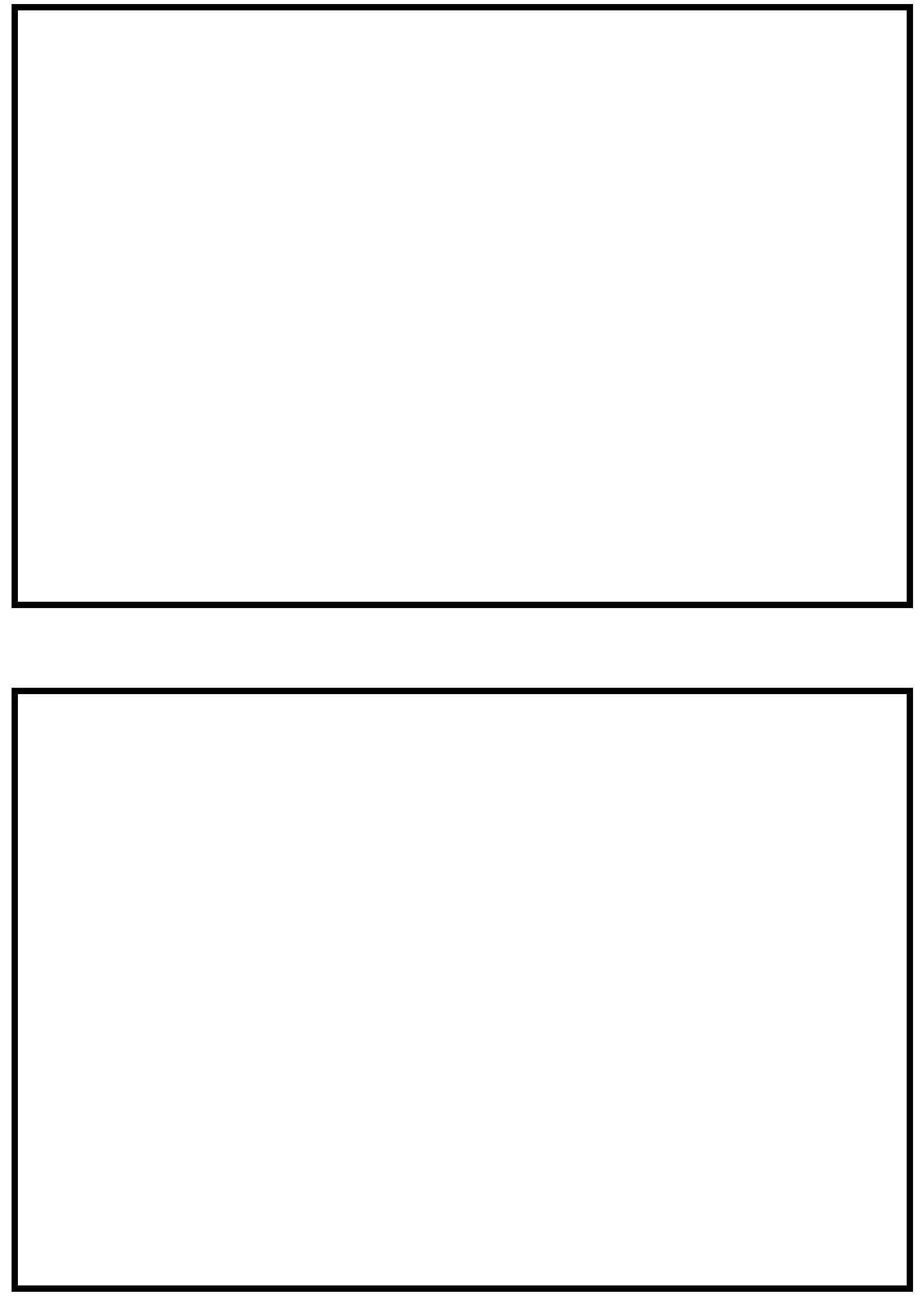


\section{LEVEL II SUMMARY}

\begin{tabular}{llllll} 
Structure Number & CHESTH00090063 & Stream & \multicolumn{2}{l}{ Williams River } \\
& Road & TH9 & & \\
County & Windsor & Ristrict &
\end{tabular}

\section{Description of Bridge}

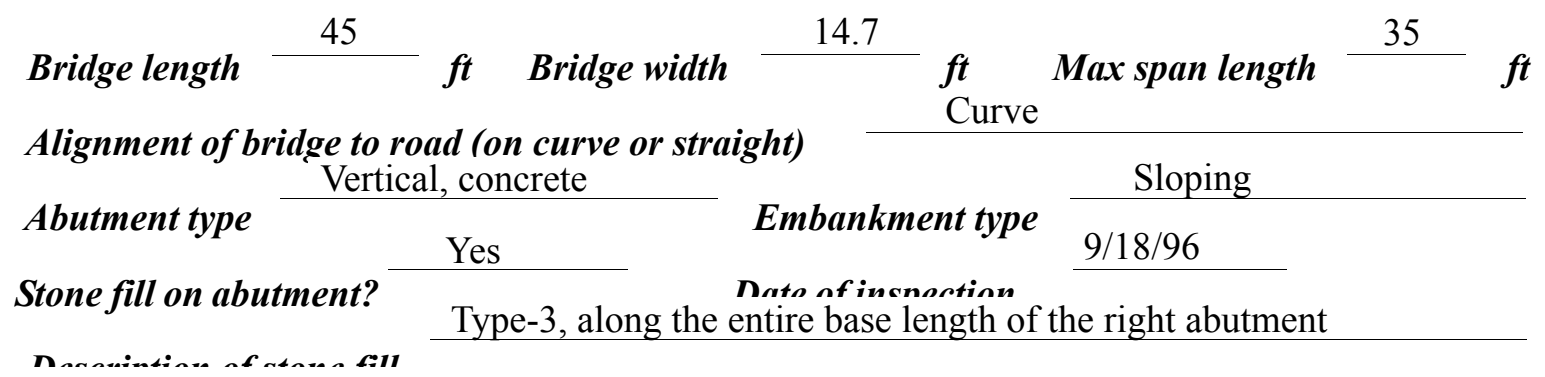

Abutments and wingwalls are concrete. The right

abutment is formed by stacked 3' x 3' x 3' concrete blocks while the left abutment is poured concrete. There is a 1.75 foot deep scour hole along the left abutment.

Is bridge skewed to flood flow according to No survey? $\quad \begin{aligned} & \mathrm{Y} \\ & \text { Angle }\end{aligned}$

Debris accumulation on bridge at time of Level I or Level II site visit:

\begin{tabular}{|c|c|c|c|}
\hline & $\begin{array}{c}\text { Date of insmortion } \\
9 / 18 / 96 \\
\end{array}$ & $\begin{array}{l}\text { Percent of rlommal } \\
\text { blocked inortzontatly }\end{array}$ & $\begin{array}{l}\text { Percent of } 0 \\
\text { blocked verticatty }\end{array}$ \\
\hline & $9 / 18 / 96$ & 0 & 0 \\
\hline
\end{tabular}

Level II

Moderate. The channel is sinuous with cutbanks evident and tree cover on the banks immediately adjacent to the channel upstream.

Potential for debris

In an extreme flood event, the right floodplain will provide relief by accepting all excess flow Doscriho anv, foaturos noar ar at tho hridoo that mav, affort flow, (includo ahsorvation datol 


\section{Description of the Geomorphic Setting}

General topography The channel is located within a wide, flat to slightly irregular flood plain. 9/18/96

Geomorphic conditions at bridge site: downstream (DS), upstream (US)

Date of inspection Steep channel

DS left: $\quad$ bank to a narrow flood plain.

DS right: $\quad$ Steep channel bank to a wide flood plain.

US left: $\quad$ Steep channel bank to a narrow flood plain.

US right: Steep channel bank to a wide flood plain.

\section{Description of the Channel}

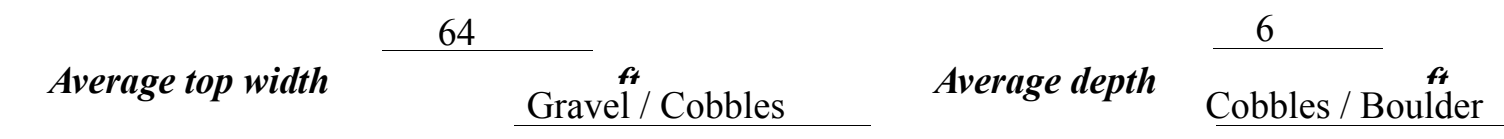

Predominant bed material

Bank material

Sinuous but stable

with semi-allúvial channel boundaries.

$9 / 18 / 96$

Vegetative co 1 TH 9 on overbank with brush and trees along banks

DS left: $\quad$ Grass on overbank with trees and brush along the banks.

DS right: $\quad$ TH 9 on overbank with brush and trees along banks

US left: $\quad$ Grass on overbank with trees and brush along the banks.

US right: $\quad$ Yes

Do banks appear stable? It was noted that although cutbanks are evident both upstream and

downstream the channel is constrained by rock protection and one $\mathrm{ft}$ (and larger) diameter trees
date of observatton. are growing along the lower banks, indicating that the channel has not moved recently. 9/18/96

None. 9/18/96.

Describe any obstructions in channel and date of observation. 


\section{Hydrology}

Drainage area $\stackrel{24.0}{m_{i}{ }^{2}}$

Percentage of drainage area in physiographic provinces: (approximate)

Physiographic province/section New England / New England Upland
Percent of drainage area 100

Is drainage area considered rural or urban? Rural Describe any significant urbanization:

There are houses along the left overbank area

Yes

Is there a USGS gage on the stream of interest?

Williams River at Brockways Mills

USGS gage description

01153500

USGS gage number 103

Gage drainage area

$m i^{2}$

Is there a lake/p -

No 


\section{Description of the Water-Surface Profile Model (WSPRO) Analysis}

Datum for WSPRO analysis (USGS survey, sea level, VTAOT plans)

USGS survey

Datum tie between USGS survey and VTAOT plans

None

Description of reference marks used to determine USGS datum. $\quad$ RM3 is a chiseled X on top of the upstream end of the left abutment (elev. $488.82 \mathrm{ft}$, arbitrary survey datum). RM4 is a nail head, four $\mathrm{ft}$ above the ground, in a telephone pole (\#CTCVT 3-1) on the right bank approximately $8 \mathrm{ft}$ downstream of the bridge face (elev. $494.40 \mathrm{ft}$, arbitrary survey datum).

\section{Cross-Sections Used in WSPRO Analysis}

\begin{tabular}{|c|c|c|c|}
\hline${ }^{1}$ Cross-section & $\begin{array}{c}\text { Section } \\
\text { Reference } \\
\text { Distance } \\
\text { (SRD) in feet }\end{array}$ & $\begin{array}{c}{ }^{2} \text { Cross-section } \\
\text { development }\end{array}$ & Comments \\
\hline EXITX & -43 & 1 & Exit section \\
\hline FULLV & 0 & 2 & $\begin{array}{l}\text { Downstream Full-valley } \\
\text { section (Templated from } \\
\text { EXITX) }\end{array}$ \\
\hline BRIDG & 0 & 1 & Bridge section \\
\hline RDWAY & 11 & 1 & Road Grade section \\
\hline APPRO & 55 & 2 & $\begin{array}{l}\text { Modelled Approach sec- } \\
\text { tion (Templated from } \\
\text { APTEM) }\end{array}$ \\
\hline APTEM & 60 & 1 & $\begin{array}{l}\text { Approach section as sur- } \\
\text { veyed (Used as a tem- } \\
\text { plate) }\end{array}$ \\
\hline
\end{tabular}

${ }^{1}$ For location of cross-sections see plan-view sketch included with Level I field form, Appendix E. For more detail on how cross-sections were developed see WSPRO input file. 


\section{Data and Assumptions Used in WSPRO Model}

Hydraulic analyses of the reach were done by use of the Federal Highway Administration's WSPRO step-backwater computer program (Shearman and others, 1986, and Shearman, 1990). The analyses reported herein reflect conditions existing at the site at the time of the study. Furthermore, in the development of the model it was necessary to assume no accumulation of debris or ice at the site. Results of the hydraulic model are presented in the Bridge Hydraulic Summary, Appendix B, and figure 7.

Channel roughness factors (Manning's " $n$ ") used in the hydraulic model were estimated using field inspections at each cross section following the general guidelines described by Arcement and Schneider (1989). Final adjustments to the values were made during the modelling of the reach. Channel " $n$ " values for the reach ranged from 0.035 to 0.055 , and overbank " $\mathrm{n}$ " values ranged from 0.032 to 0.042 .

Normal depth at the exit section (EXITX) was assumed as the starting water surface. This depth was computed by use of the slope-conveyance method outlined in the user's manual for WSPRO (Shearman, 1990). The slope used was $0.0054 \mathrm{ft} / \mathrm{ft}$ which was the slope of the 100year profile from the flood insurance study for the town of Chester (Federal Emergency Management Agency, 1982).

The surveyed approach section (APTEM) was moved along the approach channel slope $(0.0037 \mathrm{ft} / \mathrm{ft})$ to establish the modelled approach section (APPRO), one bridge length upstream of the upstream face as recommended by Shearman and others (1986). This approach also provides a consistent method for determining scour variables. 


\section{Bridge Hydraulics Summary}

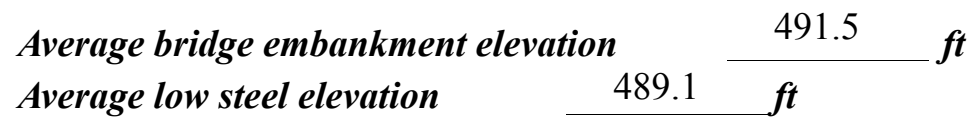

100-year discharge $\quad 5,210 \quad \mathrm{ft}^{3} / \mathrm{s}$

Water-surface elevation in bridge opening $\quad 489.2 \quad f t$

Road overtopping? ___ Y Discharge over road _ـ 2,654 $\mathrm{ft}^{3} / \mathrm{s}$

\begin{tabular}{lcc} 
Area of flow in bridge opening & $303 \quad \mathrm{ft}^{2}$ \\
\cline { 2 - 3 } Average velocity in bridge opening & 8.6 & $\mathrm{ft} / \mathrm{s}$
\end{tabular}

Maximum WSPRO tube velocity at bridge $10.2 \mathrm{ft} / \mathrm{s}$

Water-surface elevation at Approach section with bridge 491.3

Water-surface elevation at Approach section without bridge $\quad 489.7$

Amount of backwater caused by bridge $\quad 1.6 \mathrm{ft}$

500-year discharge $\quad 7,640 \quad \mathrm{ft}^{3} / \mathrm{s}$

Water-surface elevation in bridge opening $\quad 489.2 \mathrm{ft}$

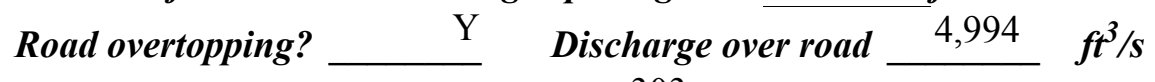

Area of flow in bridge opening $\quad 303 \quad \mathrm{fi}^{2}$

Average velocity in bridge opening $\quad 8.8 \mathrm{ft} / \mathrm{s}$

Maximum WSPRO tube velocity at bridge 10.6 's

Water-surface elevation at Approach section with bridge 492.1

Water-surface elevation at Approach section without bridge $\quad 490.5$

Amount of backwater caused by bridge $\quad 1.6 \quad f t$

Incipient overtopping discharge $\quad 2,280 \quad \mathrm{ft}^{3} / \mathrm{s}$

Water-surface elevation in bridge opening $487.7 \quad t$

Area of flow in bridge opening $\quad 259 \quad \mathrm{ft}^{2}$

Average velocity in bridge opening $\quad 8.8 \quad \mathrm{ft} / \mathrm{s}$

Maximum WSPRO tube velocity at bridge $11.1 \mathrm{ft} / \mathrm{s}$

Water-surface elevation at Approach section with bridge

Water-surface elevation at Approach section without bridge

489.0

Amount of backwater caused by bridge $\quad$\begin{tabular}{lll}
$0.5 \quad f t$ \\
\hline
\end{tabular}

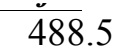




\section{Scour Analysis Summary}

\section{Special Conditions or Assumptions Made in Scour Analysis}

Scour depths were computed using the general guidelines described in Hydraulic Engineering Circular 18 (Richardson and others, 1995). Scour depths were calculated assuming an infinite depth of erosive material and a homogeneous particle-size distribution. The results of the scour analysis are presented in tables 1 and 2 and a graph of the scour depths is presented in figure 8 .

Contraction scour for the incipient road-overflow discharge model was computed by use of Laursen's clear-water contraction scour equation (Richardson and others, 1995, p. 32, equation 20). The 100- and 500-year discharge models resulted in submerged orifice flow with road overflow. Contraction scour at bridges with orifice flow is best estimated by use of the Chang pressure-flow scour equation (oral communication, J. Sterling Jones, October 4, 1996). Thus, the Chang equation (Richardson and others, 1995, pp. 145-146) was applied

to compute the contraction scour for the 100- and 500-year discharges. The results of Laursen's clear-water contraction scour were also computed for these discharges and can be found in appendix F. All of the models resulted in a computed contraction scour of $0.0 \mathrm{ft}$.

Abutment scour was computed by use of the Froehlich equation (Richardson and others, 1995, p. 48, equation 28). Variables for the Froehlich equation include the Froude number of the flow approaching the embankments, the length of the embankment blocking flow, and the depth of flow approaching the embankment less any roadway overtopping. 


\section{Scour Results}

100-yr discharge 500-yr discharge

overtopping

Contraction scour:

(Scour depths in feet)

Main channel

Live-bed scour

Clear-water scour

Depth to armoring

Left overbank

Right overbank

Local scour:

Abutment scour

Left abutment

10.1

11.0

10.1

$15.1-$

$14.4-$

14.1-

Right abutment

Pier scour

Pier 1

Pier 2

Pier 3

Abutments:

Left abutment

Right abutment

Piers:

Pier 1

Pier 2

\section{Riprap Sizing}

Incipient overtopping 100-yrdischarge 500-yrdischarge discharge

1.4

1.4

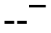

$--$

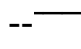
( $D_{50}$ in feet)

$1.5 \quad 1.5$
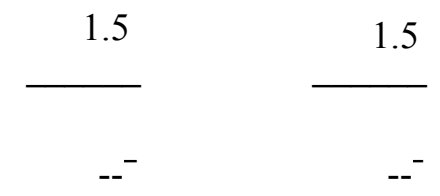

$--$

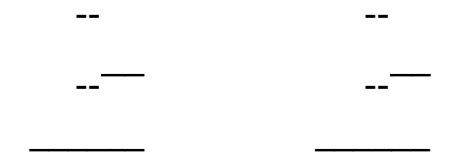




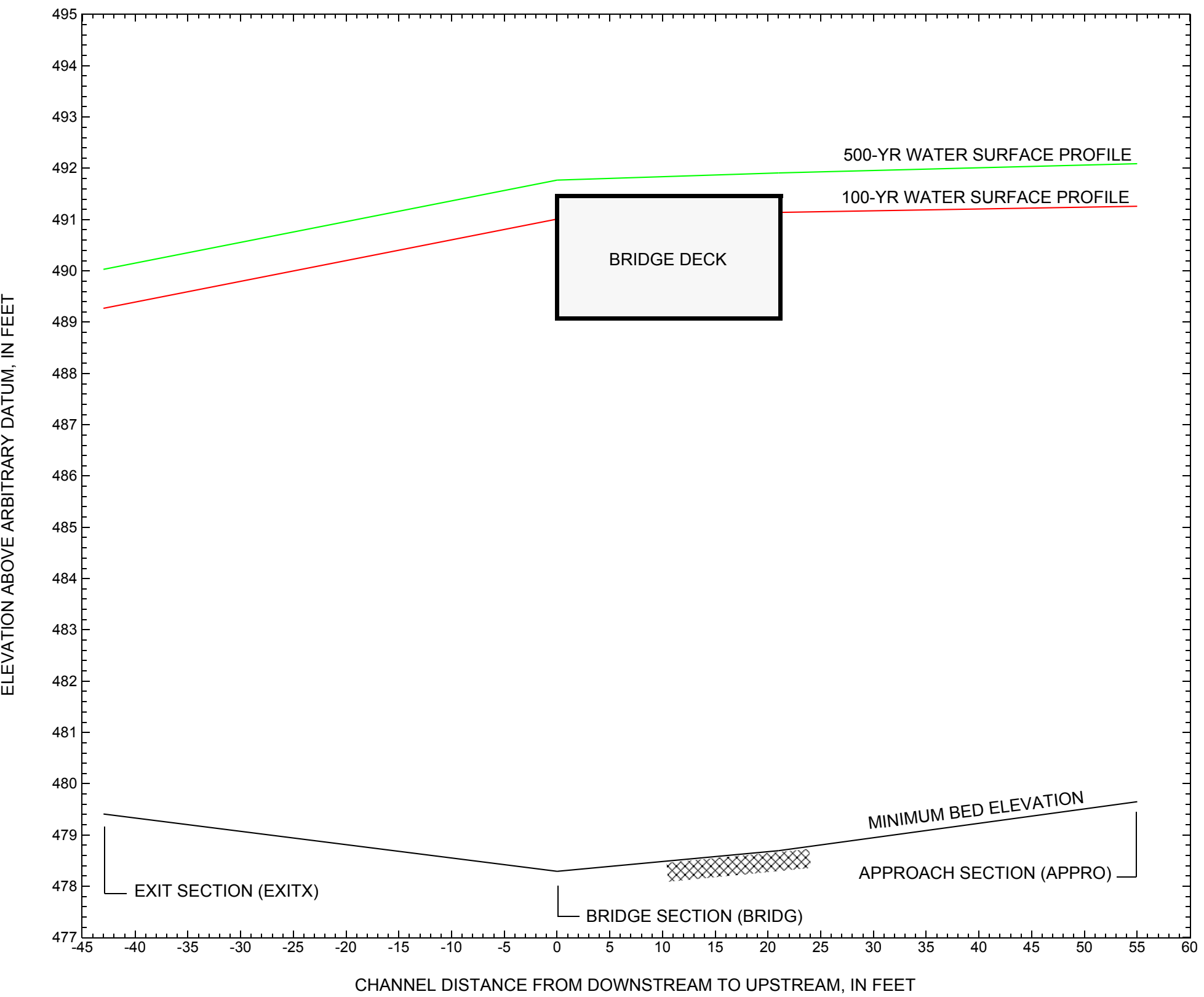

Figure 7. Water-surface profiles for the 100- and 500-yr discharges at structure CHESTH00090063 on Town Highway 9, crossing the Williams River, Chester, Vermont. 


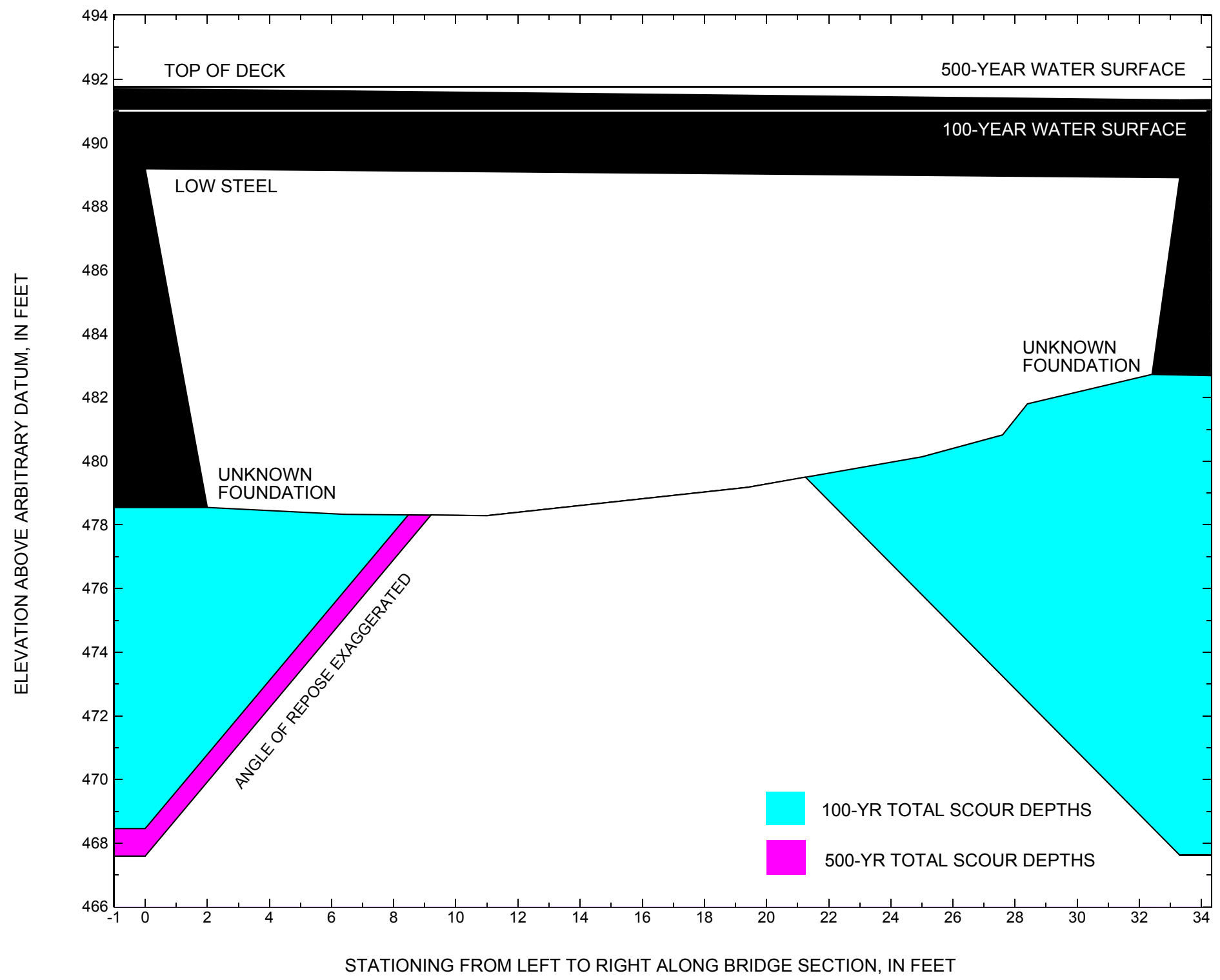

Figure 8. Scour elevations for the 100-yr and 500-yr discharges at structure CHESTH00090063 on Town Highway 9, crossing the Williams River, Chester, Vermont. 
Table 1. Remaining footing/pile depth at abutments for the 100-year discharge at structure CHESTH00090063 on Town Highway 9, crossing the Williams River, Chester, Vermont.

[VTAOT, Vermont Agency of Transportation; --,no data]

\begin{tabular}{|c|c|c|c|c|c|c|c|c|c|c|c|}
\hline Description & Station $^{1}$ & $\begin{array}{l}\text { VTAOT } \\
\text { minimum } \\
\text { low-chord } \\
\text { elevation } \\
\text { (feet) }\end{array}$ & $\begin{array}{l}\text { Surveyed } \\
\text { minimum } \\
\text { low-chord } \\
\text { elevation }{ }^{2} \\
\text { (feet) }\end{array}$ & $\begin{array}{c}\text { Bottom of } \\
\text { footing } \\
\text { elevation } \\
\text { (feet) }\end{array}$ & $\begin{array}{c}\text { Channel } \\
\text { elevation at } \\
\text { abutment/ } \\
\text { pier }^{2} \\
\text { (feet) }\end{array}$ & $\begin{array}{l}\text { Contraction } \\
\text { scour depth } \\
\text { (feet) }\end{array}$ & $\begin{array}{l}\text { Abutment } \\
\text { scour } \\
\text { depth } \\
\text { (feet) }\end{array}$ & $\begin{array}{l}\text { Pier } \\
\text { scour } \\
\text { depth } \\
\text { (feet) }\end{array}$ & $\begin{array}{l}\text { Depth of } \\
\text { total scour } \\
\text { (feet) }\end{array}$ & $\begin{array}{c}\text { Elevation of } \\
\text { scour }^{2} \\
\text { (feet) }\end{array}$ & $\begin{array}{c}\text { Remaining } \\
\text { footing/pile } \\
\text { depth } \\
\text { (feet) }\end{array}$ \\
\hline \multicolumn{12}{|c|}{100 -yr. discharge is 5,210 cubic-feet per second } \\
\hline Left abutment & 0.0 & -- & 489.2 & -- & 478.6 & 0.0 & 10.1 & -- & 10.1 & 468.5 & -- \\
\hline Right abutment & 33.3 & -- & 488.9 & -- & 482.7 & 0.0 & 15.1 & -- & 15.1 & 467.6 & -- \\
\hline
\end{tabular}

1.Measured along the face of the most constricting side of the bridge.

2.Arbitrary datum for this study.

Table 2. Remaining footing/pile depth at abutments for the 500-year discharge at structure CHESTH00090063 on Town Highway 9, crossing the Williams River, Chester, Vermont.

[VTAOT, Vermont Agency of Transportation; --, no data]

\begin{tabular}{|c|c|c|c|c|c|c|c|c|c|c|c|}
\hline Description & Station $^{1}$ & $\begin{array}{l}\text { VTAOT } \\
\text { minimum } \\
\text { low-chord } \\
\text { elevation } \\
\text { (feet) }\end{array}$ & $\begin{array}{c}\text { Surveyed } \\
\text { minimum } \\
\text { low-chord } \\
\text { elevation } \\
\text { (feet) }\end{array}$ & $\begin{array}{c}\text { Bottom of } \\
\text { footing } \\
\text { elevation } \\
\text { (feet) }\end{array}$ & $\begin{array}{c}\text { Channel } \\
\text { elevation at } \\
\text { abutment/ } \\
\text { pier }^{2} \\
\text { (feet) }\end{array}$ & $\begin{array}{l}\text { Contraction } \\
\text { scour depth } \\
\text { (feet) }\end{array}$ & $\begin{array}{l}\text { Abutment } \\
\text { scour } \\
\text { depth } \\
\text { (feet) }\end{array}$ & $\begin{array}{l}\text { Pier } \\
\text { scour } \\
\text { depth } \\
\text { (feet) }\end{array}$ & $\begin{array}{l}\text { Depth of } \\
\text { total scour } \\
\text { (feet) }\end{array}$ & $\begin{array}{c}\text { Elevation of } \\
\text { scour }^{2} \\
\text { (feet) }\end{array}$ & $\begin{array}{c}\text { Remaining } \\
\text { footing/pile } \\
\text { depth } \\
\text { (feet) }\end{array}$ \\
\hline \multicolumn{12}{|c|}{500 -yr. discharge is 7,640 cubic-feet per second } \\
\hline Left abutment & 0.0 & -- & 489.2 & -- & 478.6 & 0.0 & 11.0 & -- & 11.0 & 467.6 & -- \\
\hline Right abutment & 33.3 & -- & 488.9 & -- & 482.7 & 0.0 & 14.4 & -- & 14.4 & 468.3 & -- \\
\hline
\end{tabular}

1.Measured along the face of the most constricting side of the bridge.

2.Arbitrary datum for this study. 


\section{SELECTED REFERENCES}

Arcement, G.J., Jr., and Schneider, V.R., 1989, Guide for selecting Manning's roughness coefficients for natural channels and flood plains:

U.S. Geological Survey Water-Supply Paper 2339, 38 p.

Barnes, H.H., Jr., 1967, Roughness characteristics of natural channels: U.S. Geological Survey Water-Supply Paper 1849,213 p.

Benson, M. A., 1962, Factors Influencing the Occurrence of Floods in a Humid Region of Diverse Terrain: U.S. Geological Survey WaterSupply Paper 1580-B, 64 p.

Brown, S.A. and Clyde, E.S., 1989, Design of riprap revetment: Federal Highway Administration Hydraulic Engineering Circular No. 11, Publication FHWA-IP-89-016, 156 p.

Federal Highway Administration, 1983, Runoff estimates for small watersheds and development of sound design: Federal Highway Administration Report FHWA-RD-77-158.

Federal Highway Administration, 1993, Stream Stability and Scour at Highway Bridges: Participant Workbook: Federal Highway Administration Report FHWA-HI-91-011.

Federal Emergency Management Agency, 1982, Flood Insurance Study, Town of Chester, Windsor County, Vermont: Washington, D.C., February 1982.

Froehlich, D.C., 1989, Local scour at bridge abutments in Ports, M.A., ed., Hydraulic Engineering--Proceedings of the 1989 National Conference on Hydraulic Engineering: New York, American Society of Civil Engineers, p. 13-18.

Hayes, D.C.,1993, Site selection and collection of bridge-scour data in Delaware, Maryland, and Virginia: U.S. Geological Survey WaterResources Investigation Report 93-4017, 23 p.

Interagency Advisory Committee on Water Data, 1982, Guidelines for determining flood flow frequency: U.S. Geological Survey, Bulletin 17B of the Hydrology Subcommittee, 190 p.

Johnson, C.G. and Tasker, G.D.,1974, Progress report on flood magnitude and frequency of Vermont streams: U.S. Geological Survey OpenFile Report 74-130, 37 p.

Lagasse, P.F., Schall, J.D., Johnson, F., Richardson, E.V., Chang, F., 1995, Stream Stability at Highway Structures: Federal Highway Administration Hydraulic Engineering Circular No. 20, Publication FHWA-IP-90-014, 144 p.

Laursen, E.M., 1960, Scour at bridge crossings: Journal of the Hydraulics Division, American Society of Civil Engineers, v. 86, no. HY2, p. 39-53.

Potter, W. D., 1957a, Peak rates of runoff in the Adirondack, White Mountains, and Maine woods area, Bureau of Public Roads

Potter, W. D., 1957b, Peak rates of runoff in the New England Hill and Lowland area, Bureau of Public Roads

Richardson, E.V. and Davis, S.R., 1995, Evaluating scour at bridges: Federal Highway Administration Hydraulic Engineering Circular No. 18, Publication FHWA-IP-90-017, 204 p.

Richardson, E.V., Simons, D.B., and Julien, P.Y., 1990, Highways in the river environment: Federal Highway Administration Publication FHWA-HI-90-016.

Ritter, D.F., 1984, Process Geomorphology: W.C. Brown Co., Debuque, Iowa, 603 p.

Shearman, J.O., 1990, User's manual for WSPRO--a computer model for water surface profile computations: Federal Highway Administration Publication FHWA-IP-89-027, 187 p.

Shearman, J.O., Kirby, W.H., Schneider, V.R., and Flippo, H.N., 1986, Bridge waterways analysis model; research report: Federal Highway Administration Publication FHWA-RD-86-108, 112 p.

Talbot, A.N., 1887, The determination of water-way for bridges and culverts.

U.S. Department of Transportation, 1993, Stream stability and scour at highway bridges, Participant Workbook: Federal Highway Administration Publication FHWA HI-91-011.

U.S. Geological Survey, 1972, Chester, Vermont 7.5 Minute Series quadrangle map: U.S. Geological Survey Topographic Maps, Scale $1: 24,000$. 


\section{APPENDIX A: \\ WSPRO INPUT FILE}




\section{WSPRO INPUT FILE}

*

BR

GR

GR

GR

*

CD

$\mathrm{N}$

$\mathrm{XR}$

GR

GR

GR

GR

*

GR

GR

GR

GR

GR

GR

*

AS

GT

$\mathrm{N}$

SA

HP 1 BRIDG

HP 2 BRIDG

HP 2 RDWAY

HP 1 APPRO

HP 2 APPRO

HP 1 BRIDG

HP 2 BRIDG

HP 2 RDWAY

HP 1 APPRO

HP 2 APPRO

U.S. Geological Survey WSPRO Input File ches063.wsp

Hydraulic analysis for structure CHESTH00090063 Date: 19-FEB-97

Bridge \#63 over the Williams River in Chester, VT. RHF

$\begin{array}{lllllllllllllllllllll}6 & 29 & 30 & 552 & 553 & 551 & 5 & 16 & 17 & 13 & 3 & * & 15 & 14 & 23 & 21 & 11 & 12 & 4 & 7 & 3\end{array}$

$5210.0 \quad 7640.0 \quad 2280.0$

$0.0054 \quad 0.0054 \quad 0.0054$

EXITX $-43 \quad 0$.

$-229.7,518.86-223.3,510.97$

$-25.1,491.35-12.1,488.58$

$-83.2,493.31 \quad-47.4,491.62$

$-9.4,485.22 \quad-4.1,482.05$

$2.8,479.52$

$14.7,479.73$

$15.8,479.41$

$19.7,480.19$

$20.4,480.82$

$32.9,485.94$

$23.2,481.58$

$43.2,486.94 \quad 348.7,487.75$

$354.8,489.33$

$395.2,491.03$

$521.8,494.81$

$683.6,501.47$

0.037

0.055

0.035

43.2

BRIDG

$\begin{array}{ccc}\text { SRD } & \text { LSEL } & \text { XSSKEW } \\ 0 & 489.05 & 0.0 \\ 0.0, & 489.19 & 1.8,480.80 \\ 11.0, & 478.29 & 19.4,479.18 \\ 28.4, & 481.80 & 32.4,482.73\end{array}$

$2.0,478.55$
$25.0,480.14$
$33.3,488.91$

$6.4,478.33$

$27.6,480.83$

$0.0,489.19$

BRTYPE BRWDTH WWANGL WWWID

$128.9 *$ * $44.4 \quad 5.6$

0.035

SRD EMBWID IPAVE

$$
\begin{array}{rr}
11 & 14 \\
-164.3, & 501.81 \\
-4.9, & 491.60 \\
130.9, & 488.88 \\
391.2, & 491.44
\end{array}
$$

$$
-131
$$

$-131.5,498.29$

$0.0,491.70$

$257.9,489.00$

$459.6,493.89$

$-67.7,493.28$

$32.1,491.35$

$336.2,490.45$

$556.1,496.77$

$-185.0,500.04$

$-13.2,489.02$

$0.8,480.48$

$27.4,480.86$

$287.4,487.99$

$23.9,480$.

$42.2,487.07$

$642.4,501.37$

$55 * * * 0.0037$

0.042

$-18.0$

0.045

42.2

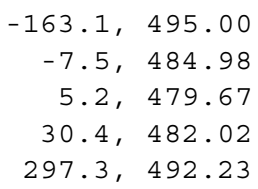

$-22.2,491.89$

$53.9,490.74$

$368.2,490.60$

$662.7,501.59$

$-50.1,492.00$

$-3.9,482.64$

$13.5,480.06$

$37.4,484.82$

$432.3,492.57$

489.191489 .19

$489.19 * * 2591$

491.01 * * 2654

491.261491 .26

491.26 * * 5210

489.191489 .19

$489.19 * * 2665$

491.77 * * 4994

492.091492 .09

492.09 * *7640 


\section{APPENDIX B: \\ WSPRO OUTPUT FILE}




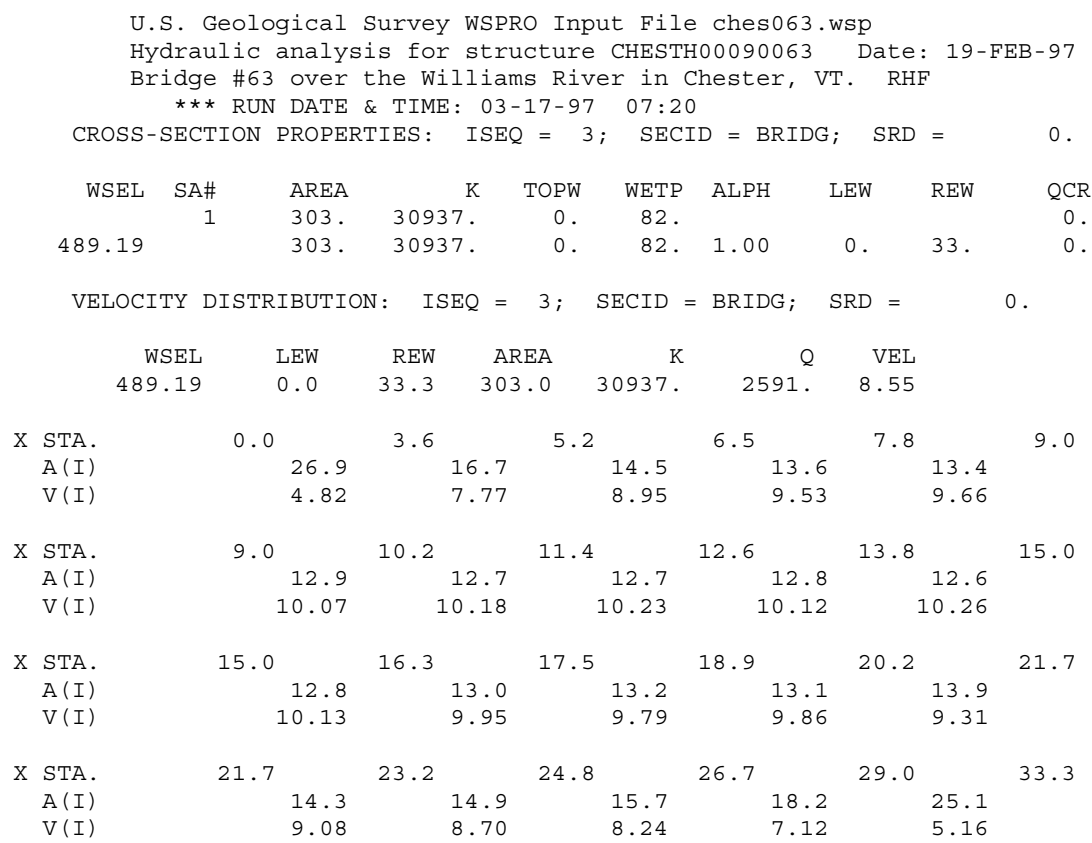

VELOCITY DISTRIBUTION : ISEQ $=4 ; \operatorname{SECID~}=$ RDWAY $; \quad \operatorname{SRD}=\quad 11$.

\begin{tabular}{|c|c|c|c|c|c|c|c|c|c|c|c|}
\hline & & SEL & LEW & REW & $\mathrm{AR}$ & $\mathrm{EA}$ & K & $Q$ & VEL & & \\
\hline & 491 & .01 & 44.3 & 379.4 & 475 & .0 & 25513. & 2654 . & 5.59 & & \\
\hline $\mathrm{X}$ & STA. & 44.3 & & 99.5 & & 116.3 & & 8.2 & 138.1 & & 147.9 \\
\hline & $A(I)$ & & 38.8 & & 26.4 & & 23.0 & 20.9 & & 20.6 & \\
\hline & $V(I)$ & & 3.42 & & 5.03 & & 5.77 & 6.34 & & 6.43 & \\
\hline $\mathrm{X}$ & STA. & 147.9 & & 157.2 & & 166.6 & & 5.9 & 185.3 & & 194.8 \\
\hline & $A(I)$ & & 19.7 & & 19.7 & & 19.4 & 19.7 & & 19.6 & \\
\hline & $V(I)$ & & 6.73 & & 6.72 & & 6.86 & 6.73 & & 6.76 & \\
\hline $\mathrm{X}$ & STA. & 194.8 & & 204.3 & & 214.1 & & 3.9 & 234.0 & & 244.4 \\
\hline & $A(I)$ & & 19.6 & & 20.1 & & 20.0 & 20.6 & & 21.2 & \\
\hline & $V(I)$ & & 6.77 & & 6.59 & & 6.64 & 6.45 & & 6.25 & \\
\hline $\mathrm{X}$ & STA. & 244.4 & & 255.3 & & 267.2 & & 2.2 & 304.4 & & 379.4 \\
\hline & $A(I)$ & & 21.9 & & 23.1 & & 25.5 & 30.2 & & 45.0 & \\
\hline & $V(I)$ & & 6.05 & & 5.75 & & 5.20 & 4.40 & & 2.95 & \\
\hline & CROSS - & SECTION & PROPER & RTIES: & ISEQ & $=$ & SECID & $=A P P R O$ & SRD & $=$ & 55. \\
\hline & WSEL & SA\# & AREA & & K & TOPW & WETP & $\mathrm{ALPH}$ & LEW & REW & QCR \\
\hline & & 1 & 6. & 11 & 9. & 17. & 17. & & & & 22 . \\
\hline & & 2 & 512. & 6771 & & 60. & 64. & & & & 8485 . \\
\hline & & 3 & 932. & 103314 & & 253. & 254 . & & & & 10149. \\
\hline & 491.26 & & 1451 . & 17114 & & 330. & 334 . & 1.03 & 35 . & 295. & 17020 . \\
\hline
\end{tabular}

VELOCITY DISTRIBUTION : ISEQ $=5 ; \quad \operatorname{SECID}=$ APPRO $; \quad$ SRD $=55$.

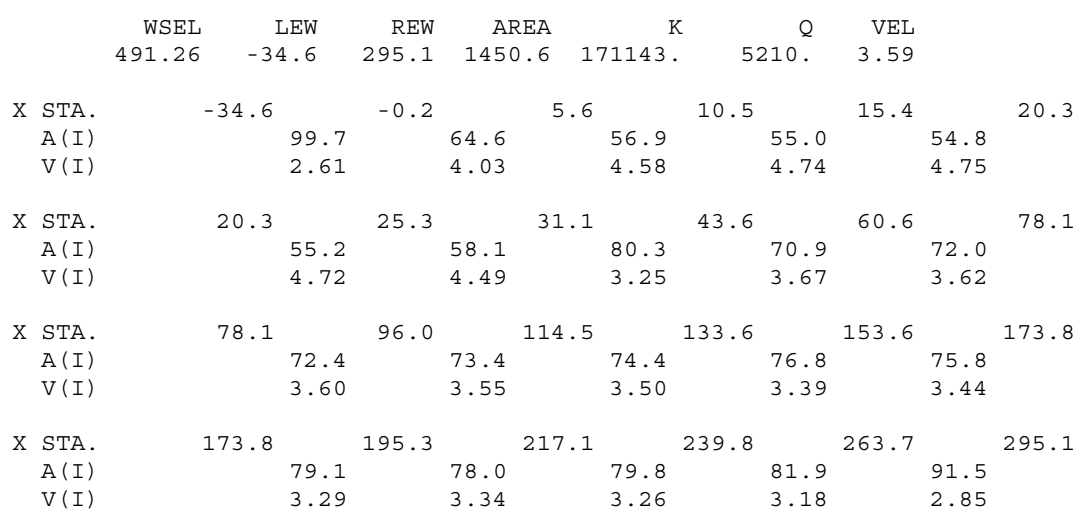




\begin{tabular}{|c|c|c|c|c|c|c|c|c|c|c|c|}
\hline & & ISEL & LEW & REW & $A R$ & EA & K & $Q$ & VEL & & \\
\hline & 49 &. .77 & -15.0 & 400.4 & 754 & .2 & 51190. & 4994. & 6.62 & & \\
\hline $\mathrm{X}$ & STA. & -15. & & 82.4 & & 103.3 & & 8.2 & 130.4 & & 141.5 \\
\hline & $A(I)$ & & 64.3 & & 41.2 & & 35.8 & 33.3 & & 31.9 & \\
\hline & $V(I)$ & & 3.89 & & 6.06 & & 6.97 & 7.49 & & 7.82 & \\
\hline $\mathrm{X}$ & STA. & 141. & & 152.2 & & 163.2 & & 4.1 & 185.2 & & 196.3 \\
\hline & $A(I)$ & & 30.8 & & 31.6 & & 31.0 & 31.6 & & 31.5 & \\
\hline & $V(I)$ & & 8.11 & & 7.90 & & 8.05 & 7.90 & & 7.93 & \\
\hline $\mathrm{X}$ & STA. & 196. & & 207.5 & & 219.0 & & 0.4 & 242.2 & & 254.5 \\
\hline & $A(I)$ & & 31.4 & & 32.3 & & 32.1 & 33.0 & & 34.1 & \\
\hline & $V(I)$ & & 7.95 & & 7.73 & & 7.79 & 7.56 & & 7.32 & \\
\hline $\mathrm{X}$ & STA. & 254 & & 267.6 & & 283.2 & & 2.2 & 331.9 & & 400.4 \\
\hline & $A(I)$ & & 35.4 & & 38.2 & & 40.4 & 49.7 & & 64.5 & \\
\hline & $V(I)$ & & 7.06 & & 6.54 & & 6.18 & 5.03 & & 3.87 & \\
\hline & CROSS & SECTION & N PROPER & RTIES: & ISEQ & $=$ & SECID & $=\mathrm{APPRO}$ & SRD & $=$ & 55. \\
\hline & WSEL & SA\# & AREA & & K & TOPW & WETP & ALPH & LEW & REW & QCR \\
\hline & & 1 & 28 . & 818 & & 36. & 36. & & & & 137. \\
\hline & & 2 & 562. & 79066 & & 60. & 64. & & & & 9756. \\
\hline & & 3 & 1142 . & 144317 & & 255 . & 256 . & & & & 13727. \\
\hline & 492.09 & & 1733. & 224201 & & 351. & 356 . & 1.03 & 54. & 297. & 21518 \\
\hline
\end{tabular}

VELOCITY DISTRIBUTION $:$ ISEQ $=5 ;$ SECID $=$ APPRO $;$ SRD $=55$.

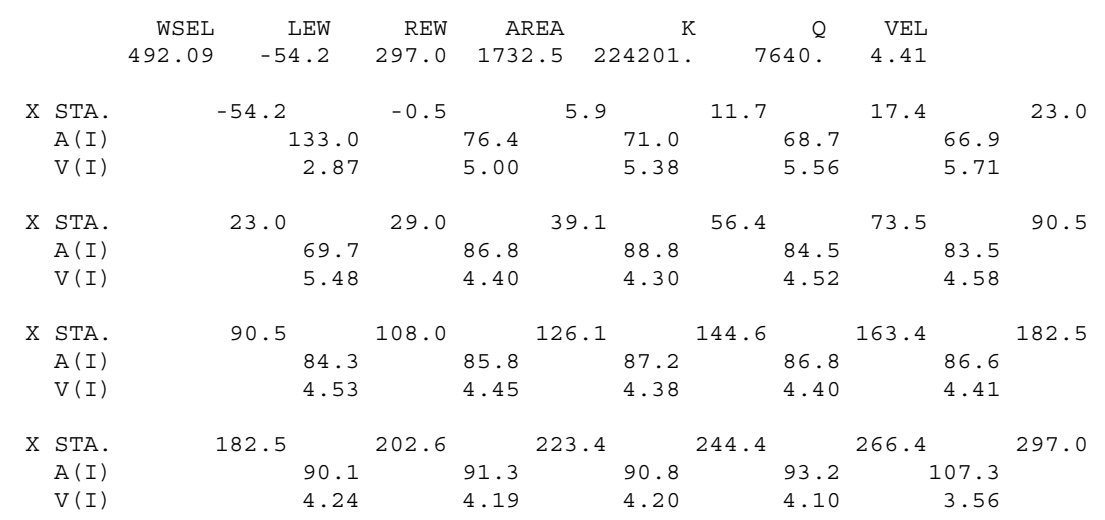


WSPRO OUTPUT FILE (continued)

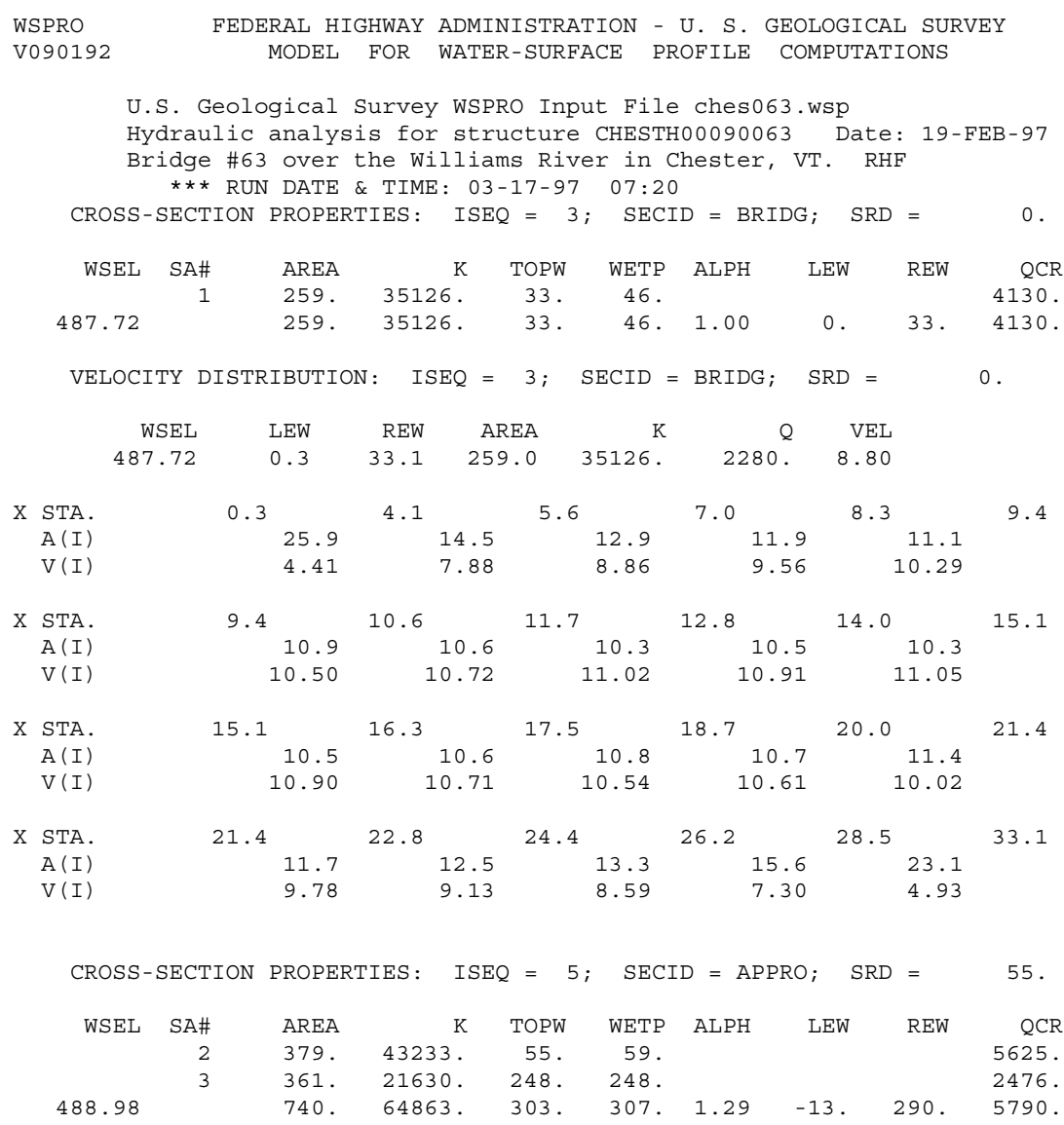

VELOCITY DISTRIBUTION : ISEQ $=5 ; \quad \operatorname{SECID}=$ APPRO; $\quad \operatorname{SRD}=55$.

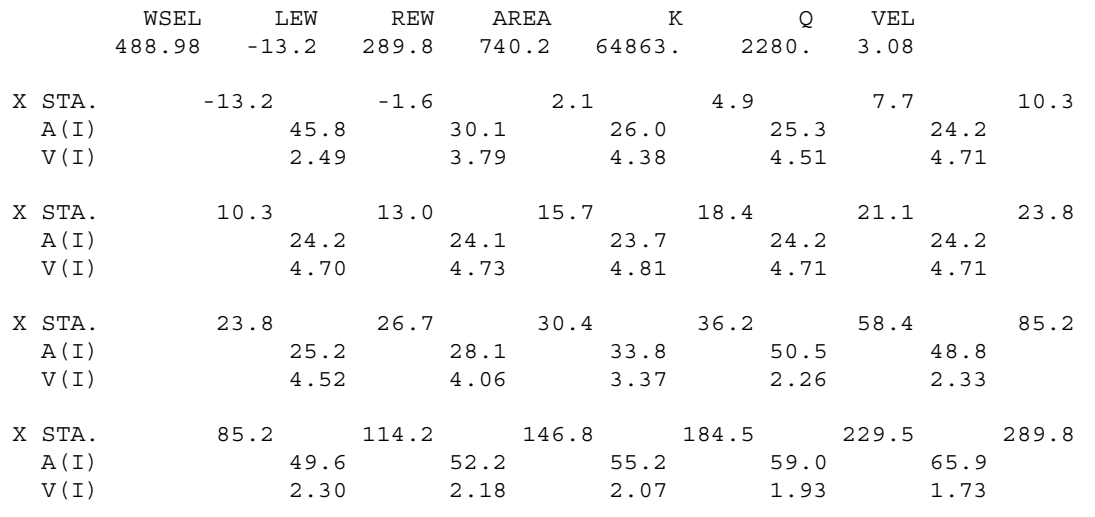


WSPRO OUTPUT FILE (continued)

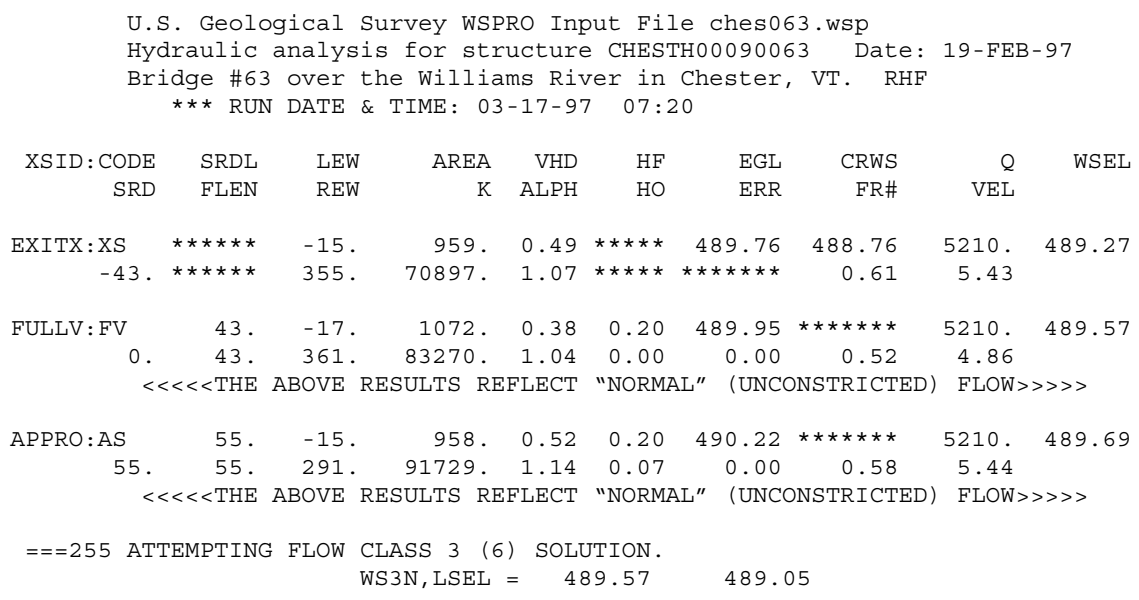


WSPRO OUTPUT FILE (continued)

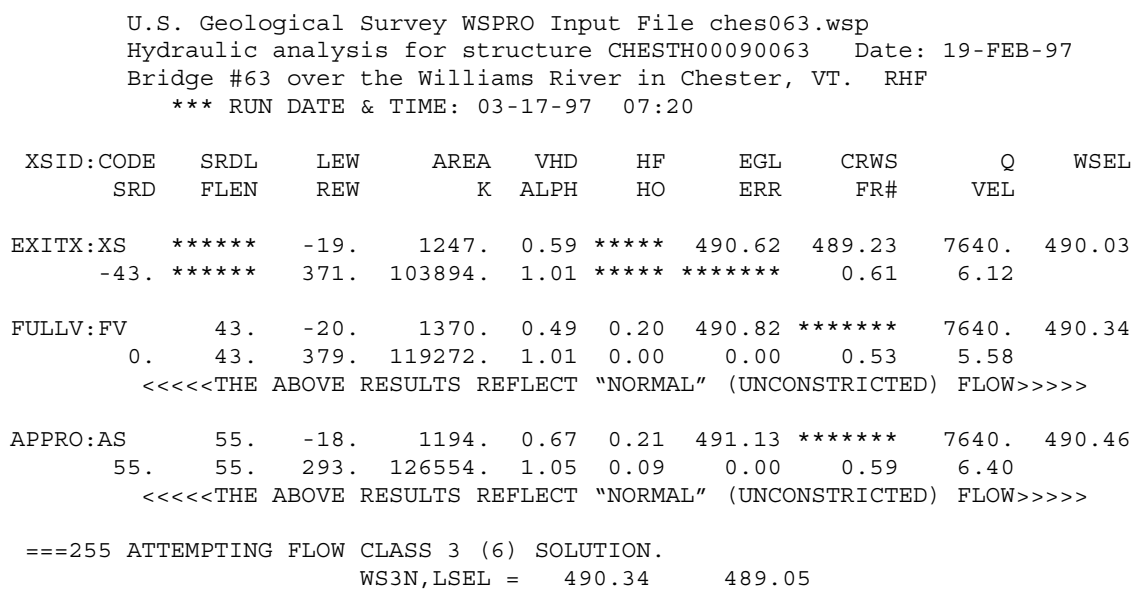


WSPRO OUTPUT FILE (continued)

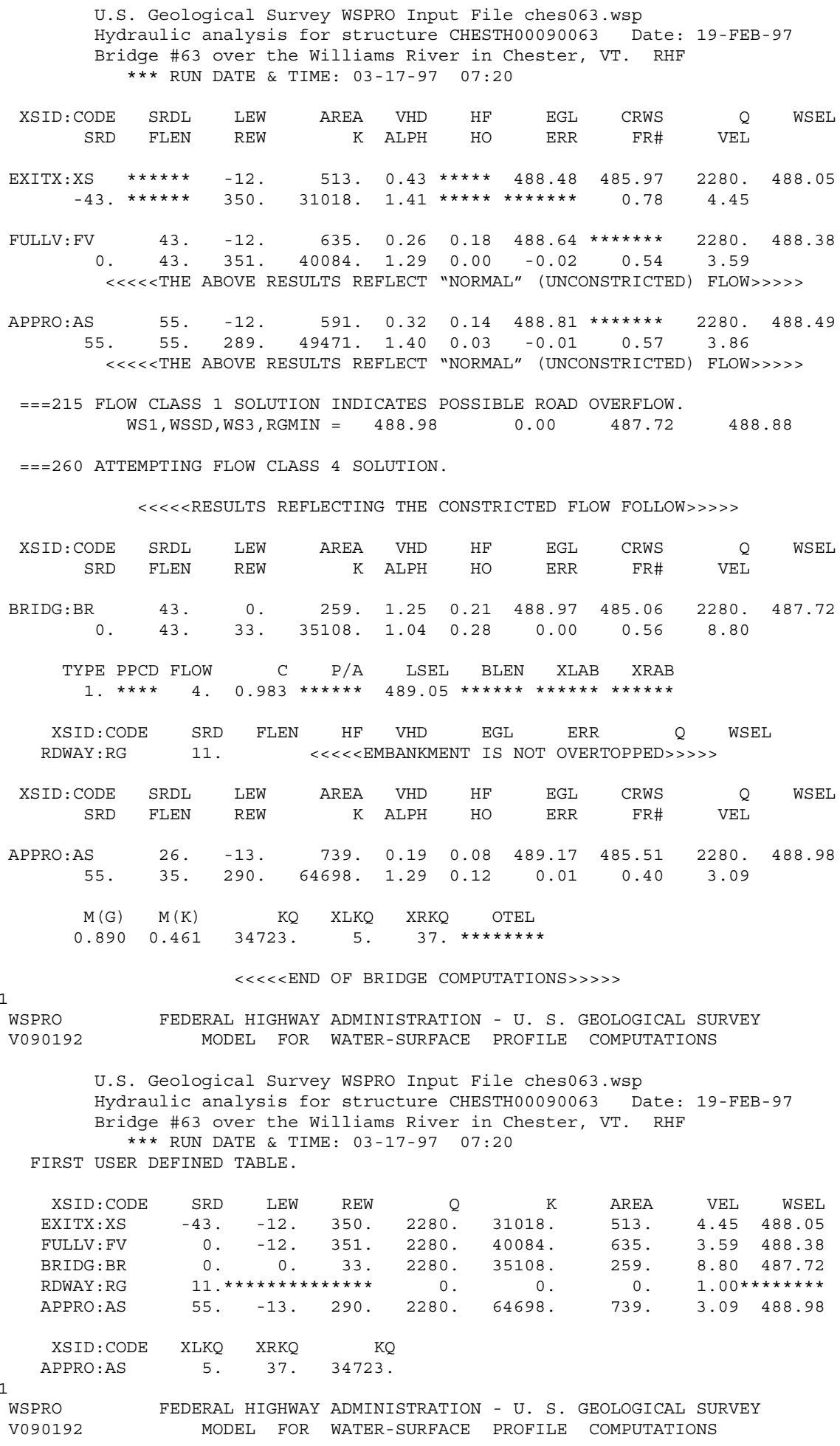




\section{APPENDIX C:}

\section{BED-MATERIAL PARTICAL-SIZE DISTRIBUTION}




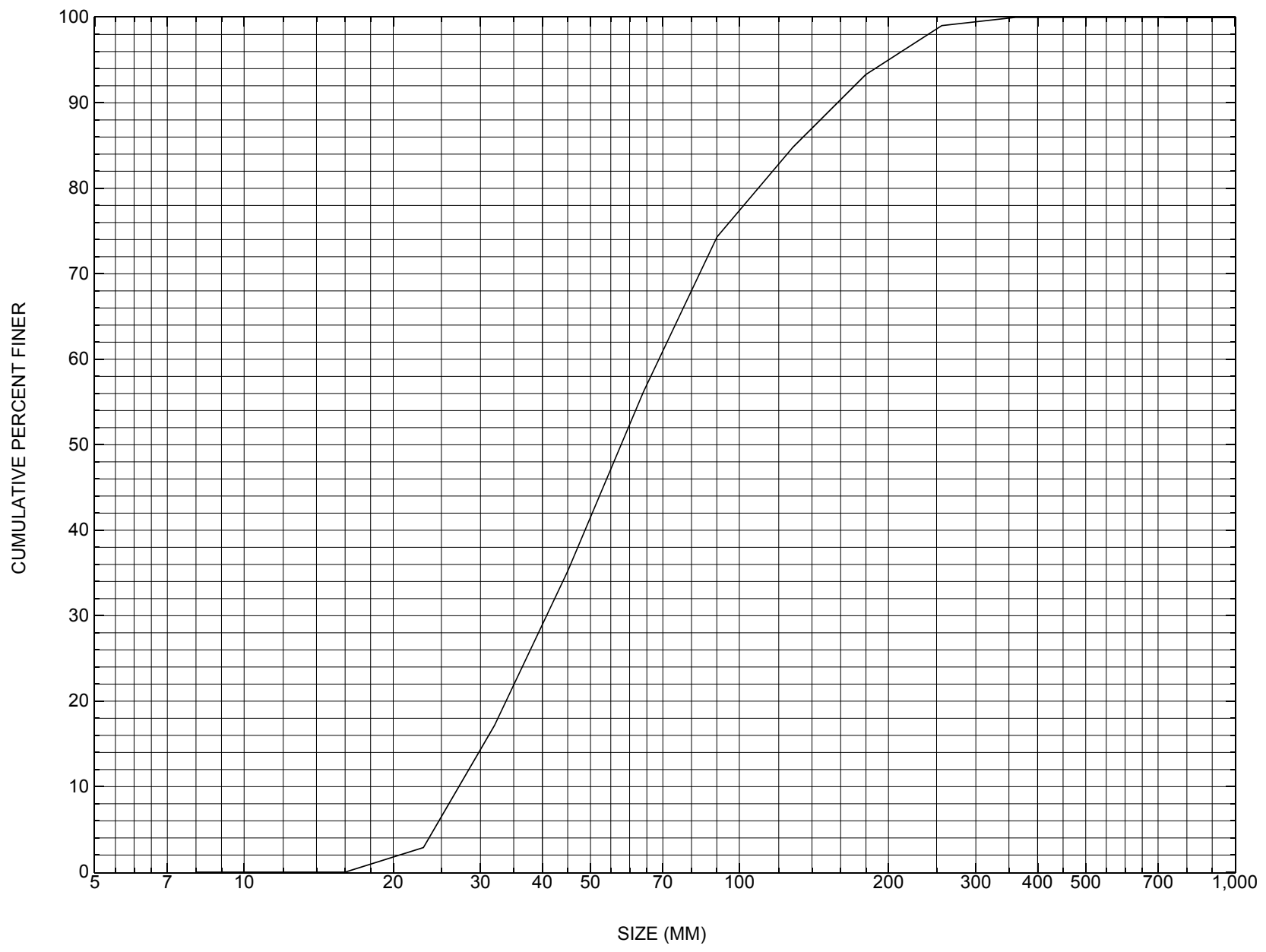

Appendix C. Bed material particle-size distribution for a pebble count in the channel approach of structure CHESTH00090063, in Chester, Vermont. 


\section{APPENDIX D: \\ HISTORICAL DATA FORM}




\section{Structure Number CHESTH00090063}

\section{General Location Descriptive}

Data collected by (First Initial, Full last name) $\underline{\text { M. IVANOFF }}$

Date $(M M / D D / Y Y) \_\mathbf{0 4} / \underline{06} / \underline{95}$

Highway District Number (I - 2; nn) $\mathbf{0 2}$

Town (FIPS place code; I - 4; nnnnn) 13600

Waterway (I - 6) WILLIAMS RIVER

Route Number TH009

Topographic Map Chester

Latitude (I - 16; nnnn.n) 43161
County (FIPS county code; I - 3; nnn)

Mile marker (I - 11; nnn.nnn) $\mathbf{0 0 0 0 0 0}$

Road Name (I - 7): -

Vicinity (I - 9)@JCT OF CL2 TH9 \& TH6

Hydrologic Unit Code: $\mathbf{0 1 0 8 0 1 0 7}$

Longitude (i - 17; nnnnn.n) $\mathbf{7 2 3 5 1}$

\section{Select Federal Inventory Codes}

FHWA Structure Number $(I-8) \quad \mathbf{1 0 1 4 0 7 0 0 6 3 1 4 0 7}$

Maintenance responsibility $(I-21 ; n n) \quad \mathbf{0 3} \quad$ Maximum span length $(I-48 ; n n n n) \underline{\mathbf{0 0 3 5}}$

Year built (I - 27; YYYY) 1919

Structure length (I - 49; nnnnnn) $\underline{\mathbf{0 0 0 0 4 5}}$

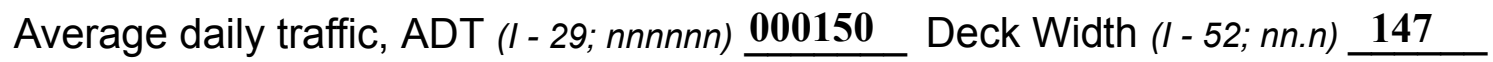

Year of ADT (I - 30; YY) $\mathbf{9 4}$

Channel \& Protection $(I-61 ; n) \underline{7}$

Opening skew to Roadway $(I-34 ; n n) \quad \mathbf{0 0}$

Waterway adequacy $(I-71 ; n)$

Operational status $(I-41 ; X)$ A

Underwater Inspection Frequency $(I-92 B ; X Y Y) \_\mathbf{N}$

Structure type (I - 43; nnn) $\mathbf{3 0 2}$

Year Reconstructed (I - 106) 1989

Approach span structure type $(I-44 ; n n n) \quad \mathbf{0 0 0}$

Clear span (nnn.n ft) _

Number of spans (I - 45; nnn) $\underline{\mathbf{0 0 1}}$

Vertical clearance from streambed (nnn.n ft) $\underline{\mathbf{9 . 0}}$

Number of approach spans (I - 46; nnnn) $\mathbf{0 0 0 0}$

Waterway of full opening $\left(n n n . n \mathrm{ft}^{2}\right)$

Comments:

The structural inspection report of $09 / 23 / 95$ indicates that the structure is a steel beam type bridge with a timber deck. The right abutment is a laid up concrete block wall with a thin concrete bearing cap. There is good stone fill along the banks at both ends of the abutment which acts as a retaining wall. The left abutment is a solid concrete wall with minor rust stains due to the structural steel above. There is some minor spalling at the bottom downstream end of the left abutment wall. The top of the right wingwall has a horizontal crack with some spalling along it. The waterway passes straight through the structure. The streambed consists of stone and gravel. The footing is not exposed along the left abutment. 


\section{Bridge Hydrologic Data}

Is there hydrologic data available? $\underline{\mathbf{N}}$ if No, type ctrl-n $h \quad$ VTAOT Drainage area $\left(m i^{2}\right)$ : -

Terrain character:

Stream character \& type: -

Streambed material:

Discharge Data (cfs):

$$
\begin{aligned}
& Q_{2.33}- \\
& Q_{50}-
\end{aligned}
$$

Record flood date $(M M / D D / Y Y)$ :

Estimated Discharge (cfs): Ice conditions (Heavy, Moderate, Light) : -

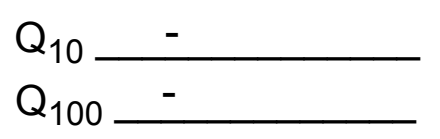

$$
\begin{aligned}
& Q_{25}- \\
& Q_{500}-
\end{aligned}
$$

Water surface elevation $(f t):-$

The stage increases to maximum highwater elevation (Rapidly, Not rapidly):

The stream response is (Flashy, Not flashy):

Describe any significant site conditions upstream or downstream that may influence the stream's stage: -

Watershed storage area (in percent): _ _ \%

The watershed storage area is: - (1-mainly at the headwaters; 2- uniformly distributed; 3-immediatly upstream oi the site)

Water Surface Elevation Estimates for Existing Structure:

\begin{tabular}{|l|l|l|l|l|l|}
\hline Peak discharge frequency & $Q_{2.33}$ & $Q_{10}$ & $Q_{25}$ & $Q_{50}$ & $Q_{100}$ \\
Water surface elevation (ft)) & - & - & - & - & - \\
Velocity (ft/sec) & - & - & - & - & - \\
\hline
\end{tabular}

Long term stream bed changes: -

Is the roadway overtopped below the $\mathrm{Q}_{100}$ ? (Yes, No, Unknown): $\mathbf{U}$ Frequency: Relief Elevation (ft): Discharge over roadway at $Q_{100}\left(f^{3} / \mathrm{sec}\right)$ :

Are there other structures nearby? (Yes, No, Unknown): $\underline{\mathbf{U}}$ Upstream distance (miles): Town: If No or Unknown, type ctrl-n os Highway No. : Structure No. : Year Built:

Clear span (ft): Clear Height $(f t)$ : Full Waterway $\left(f^{2}\right)$ : 
Downstream distance (miles): Town: Year Built:

Highway No. : Structure No. : Structure Type:

Clear span (ft): Clear Height $(f t)$ : Full Waterway $\left(f^{2}\right)$ :

Comments:

\section{USGS Watershed Data}

Watershed Hydrographic Data

Drainage area $(D A) \stackrel{23.99}{\mathrm{mi}^{2}}$ Lake and pond area

0.08 $\mathrm{mi}^{2}$

Watershed storage (ST) 0.3

Bridge site elevation 580 $\mathrm{ft}$ $\%$

Main channel length 14.55 $\mathrm{mi}$ $10 \%$ channel length elevation 620 $\mathrm{ft} \quad 85 \%$ channel length elevation $\mathrm{ft}$

Main channel slope $(S)$
(S) 87.97 $\mathrm{ft} / \mathrm{mi}$

Watershed Precipitation Data

Average site precipitation in Average headwater precipitation in

Maximum 2yr-24hr precipitation event $(124,2)$ in

Average seasonal snowfall (Sn) $\mathrm{ft}$ 


\section{Bridge Plan Data}

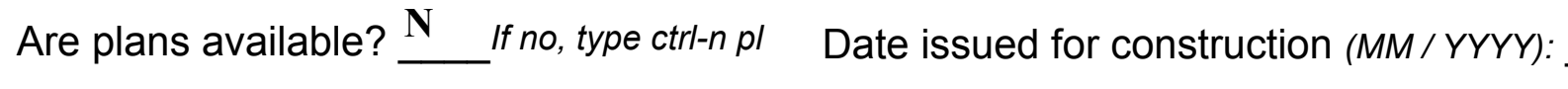

Project Number

Minimum channel bed elevation:

Low superstructure elevation: USLAB DSLAB USRAB DSRAB Benchmark location description:

NO BENCHMARK INFORMATION

Reference Point (MSL, Arbitrary, Other): Datum (NAD27, NAD83, Other):

Foundation Type: 4

If 1: Footing Thickness

If 2: Pile Type: (1-Wood; 2-Steel or metal; 3-Concrete)

If 3 : Footing bottom elevation:

Is boring information available? $\mathbf{N}$ If no, type ctrl-n bi Number of borings taken:

Foundation Material Type: $\mathbf{3}$ (1-regolith, 2-bedrock, 3-unknown)

Briefly describe material at foundation bottom elevation or around piles:

NO FOUNDATION MATERIAL INFORMATION

Comments:

NO PLANS. 


\section{Cross-sectional Data}

Is cross-sectional data available? $\mathbf{N}$ If no, type ctrl-n xs

Source (FEMA, VTAOT, Other)? -

Comments: NO CROSS SECTION INFORMATION

\begin{tabular}{|l|l|l|l|l|l|l|l|l|l|l|l|}
\hline Station & - & - & - & - & - & - & - & - & - & - & - \\
\hline Feature & - & - & - & - & - & - & - & - & - & - & - \\
\hline $\begin{array}{l}\text { Low cord } \\
\text { elevation }\end{array}$ & - & - & - & - & - & - & - & - & - & - & - \\
\hline $\begin{array}{l}\text { Bed } \\
\text { elevation }\end{array}$ & - & - & - & - & - & - & - & - & - & - & - \\
\hline $\begin{array}{l}\text { Low cord to } \\
\text { bed length }\end{array}$ & - & - & - & - & - & - & - & - & - & - & - \\
\hline Station & - & - & - & - & - & - & - & - & - & - & - \\
\hline Feature & - & - & - & - & - & - & - & - & - & - & - \\
\hline $\begin{array}{l}\text { Low cord } \\
\text { elevation }\end{array}$ & - & - & - & - & - & - & - & - & - & - & - \\
\hline $\begin{array}{l}\text { Bed } \\
\text { elevation }\end{array}$ & - & - & - & - & - & - & - & - & - & - & - \\
\hline $\begin{array}{l}\text { Low cord to } \\
\text { bed length }\end{array}$ & - & - & - & - & - & - & - & - & - & - & - \\
\hline
\end{tabular}

Source (FEMA, VTAOT, Other)?

Comments: NO CROSS SECTION INFORMATION

\begin{tabular}{|l|l|l|l|l|l|l|l|l|l|l|l|}
\hline Station & - & - & - & - & - & - & - & - & - & - & - \\
\hline Feature & - & - & - & - & - & - & - & - & - & - & - \\
\hline $\begin{array}{l}\text { Low cord } \\
\text { elevation }\end{array}$ & - & - & - & - & - & - & - & - & - & - & - \\
\hline $\begin{array}{l}\text { Bed } \\
\text { elevation }\end{array}$ & - & - & - & - & - & - & - & - & - & - & - \\
\hline $\begin{array}{l}\text { Low cord to } \\
\text { bed length }\end{array}$ & - & - & - & - & - & - & - & - & - & - & - \\
\hline Station & - & - & - & - & - & - & - & - & - & - & - \\
\hline Feature & - & - & - & - & - & - & - & - & - & - & - \\
\hline $\begin{array}{l}\text { Low cord } \\
\text { elevation }\end{array}$ & - & - & - & - & - & - & - & - & - & - & - \\
\hline $\begin{array}{l}\text { Bed } \\
\text { elevation }\end{array}$ & - & - & - & - & - & - & - & - & - & - & - \\
\hline $\begin{array}{l}\text { Low cord to } \\
\text { bed length }\end{array}$ & - & - & - & - & - & - & - & - & - & - & - \\
\hline
\end{tabular}




\section{APPENDIX E: \\ LEVEL I DATA FORM}


U. S. Geological Survey

Bridge Field Data Collection and Processing Form

Qa/Qc Check by: $\mathbf{R B}$ Date: 10/15/96

\section{Structure Number}

\section{A. General Location Descriptive}

1. Data collected by (First Initial, Full last name) R. HAMMOND

Date $(M M / D D / Y Y)$

09

$18 / 1996$

2. Highway District Number $\mathbf{0 2}$

Mile marker $\mathbf{0 0 0 0}$

County 027 WINDSOR

Waterway (I - 6) WILLIAMS RIVER

Town 1360 CHESTER

Route Number TH009

Road Name -

Hydrologic Unit Code: 01080107

3. Descriptive comments:

Located at the junction of CL2 TH9 and TH6, also 0.1 miles from the junction of TH6, Green Mountain Road, with VT 103.

\section{B. Bridge Deck Observations}
4. Surface cover... LBUS 2
RBUS 4
LBDS 2
RBDS 4
Overall 4

(2b us, ds,lb,rb: 1- Urban; 2- Suburban; 3- Row crops; 4- Pasture; 5- Shrub- and brushland; 6- Forest; 7- Wetland)
5. Ambient water surface... US 1
UB 1
DS $\underline{2}$
(1- pool; 2- riffle)

6. Bridge structure type 1 (1- single span; 2- multiple span; 3- single arch; 4- multiple arch; 5-cylindrical culvert; 6- box culvert; or 7- other)
7. Bridge length 45
(feet)
Span length $\mathbf{3 5}$
(feet)
Bridge width 14.7 (feet)

\section{Road approach to bridge:}
8. LB 2 RB 1
( 0 even, 1- lower, 2- higher)
9. $\mathrm{LB}$
RB 1
(1- Paved, 2- Not paved)

10. Embankment slope (run / rise in feet / foot):

US left

US right

\begin{tabular}{|c|c|c|c|c|}
\hline & \multicolumn{2}{|c|}{ Protection } & \multirow{2}{*}{ 13.Erosion } & \multirow{2}{*}{ 14.Severity } \\
\hline & 11.Type & 12.Cond. & & \\
\hline LBUS & $\mathbf{0}$ & $\mathbf{0}$ & 2 & 1 \\
\hline RBUS & $\mathbf{0}$ & $\mathbf{0}$ & 2 & 1 \\
\hline RBDS & $\mathbf{0}$ & $\mathbf{0}$ & $\mathbf{0}$ & $\mathbf{0}$ \\
\hline LBDS & 1 & 3 & 2 & 2 \\
\hline
\end{tabular}

Bank protection types: 0- none; 1- < 12 inches;

2- < 36 inches; 3- < 48 inches;

4- < 60 inches; 5- wall / artificial levee

Bank protection conditions: 1- good; 2- slumped;

3- eroded; 4- failed

Erosion: 0 - none; 1- channel erosion; 2-

road wash; 3- both; 4- other

Erosion Severity: 0 - none; 1- slight; 2- moderate;

Channel approach to bridge (BF):

15. Angle of approach: $\mathbf{0}$

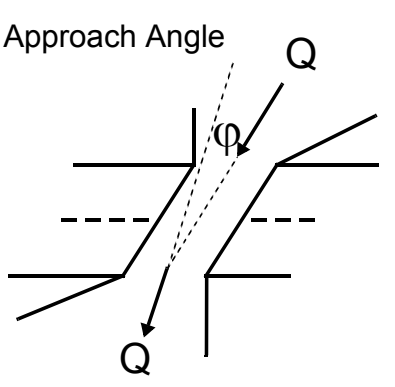

17. Channel impact zone 1 :

Where? LB (LB, RB)

Range? 110 feet US

Channel impact zone 2:

Where? LB $(L B, R B)$

Range? $\underline{90}$ feet $\underline{\text { DS }}$ (US, UB, DS) to $\underline{400}$ feet DS

Impact Severity: 0- none to very slight; 1- Slight; 2- Moderate; 3- Severe
16. Bridge skew: $\mathbf{5}$

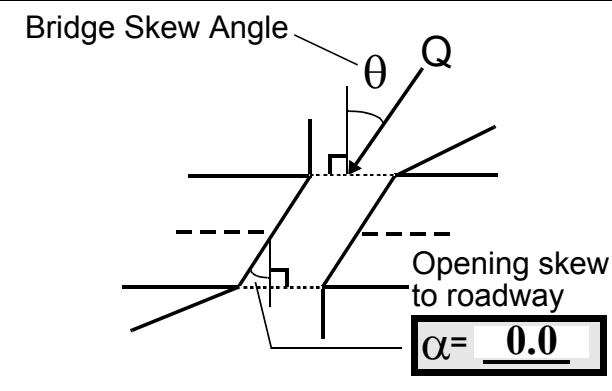

\section{Exist? $\mathbf{Y}(Y$ or $N)$}

Severity 1

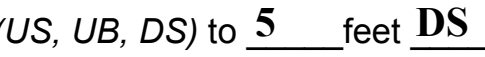

Severity $\underline{2}$
Exist? $\mathbf{Y}(Y$ or $N)$ 
18. Bridge Type: 1a

1a- Vertical abutments with wingwalls

1 b- Vertical abutments without wingwalls

2- Vertical abutments and wingwalls, sloping embankment Wingwalls perpendicular to abut. face

3- Spill through abutments

4- Sloping embankment, vertical wingwalls and abutments

Wingwall angle less than $90^{\circ}$.

19. Bridge Deck Comments (surface cover variations, measured bridge and span lengths, bridge type variations, approach overflow width, etc.)

At $350 \mathrm{ft}$. DS, the channel makes a 90 degree bend to the right where there is a severe impact.

4. The left bank has houses with lawns US and DS. The right bank is mowed grass fields both US and DS with some trees along the immediate bank.

7. Values are from the VTAOT files. Measured bridge length is $45.2 \mathrm{ft}$., span length is $33 \mathrm{ft}$., and bridge width is $14.5 \mathrm{ft}$.

\section{Upstream Channel Assessment}

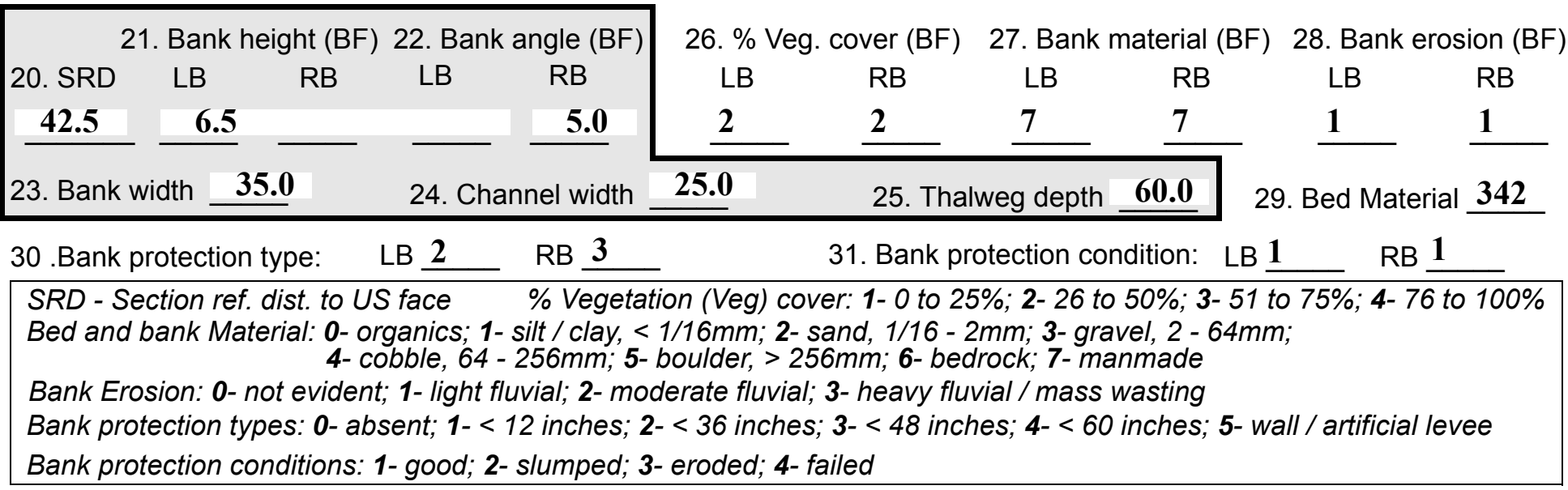

32. Comments (bank material variation, minor inflows, protection extent, etc.):

30. Protection on the right bank extends from $50 \mathrm{ft}$ US to $88 \mathrm{ft}$ US and then from $175 \mathrm{ft}$ US to $285 \mathrm{ft}$ US. The left bank protection exists from $50 \mathrm{ft}$ US to $75 \mathrm{ft}$ US, from $100 \mathrm{ft}$ US to $160 \mathrm{ft}$ US, and from $210 \mathrm{ft}$ US to $300 \mathrm{ft}$ US.

The DS corner of the Grist Mill Gallery building is $273 \mathrm{ft}$. US. 
36. Point bar extent: $\underline{\mathbf{1 1 5}}$ feet $\underline{\mathrm{US}}$ (US, UB) to $\underline{\mathbf{5 5}}$ feet $\underline{\mathrm{US}}$ (US, UB, DS) positioned $\underline{\mathbf{8 0}} \%$ LB to $\underline{\mathbf{1 0 0}} \%$ RB

37. Material: $\mathbf{3 4 2}$

38. Point or side bar comments (Circle Point or Side; Note additional bars, material variation, status, etc.):

Another channel bar exists from $260 \mathrm{ft}$. US to $170 \mathrm{ft}$. US. It is positioned from $10 \% \mathrm{LB}$ to $50 \% \mathrm{RB}$. It is comprised of gravel and sand and is $25 \mathrm{ft}$. wide with woody plants growing on it.

39. Is a cut-bank present? $\underline{\mathbf{Y}}$ ( $Y$ or if $N$ type ctrl-n $c b)$

40. Where? $\underline{\mathbf{R B}}$ (LB or RB)

41. Mid-bank distance: 160

42. Cut bank extent: $\underline{170}$ feet $\underline{\mathbf{U S}}$ (US, UB) to $\underline{\mathbf{8 8}}$ feet $\underline{\mathbf{U S}}$ (US, UB, DS)

43. Bank damage: 1

(1- eroded and/or creep; 2- slip failure; 3- block failure)

44. Cut bank comments (eg. additional cut banks, protection condition, etc.):

$-$

45. Is channel scour present? $\mathbf{Y}$ ( $Y$ or if $N$ type ctrl-n cs) 46. Mid-scour distance: 5 DS

47. Scour dimensions: Length $\underline{\mathbf{1 1 4 . 5}}$ Width $\underline{\mathbf{2 0}}$ Depth : $\underline{\mathbf{1 . 8}}$ Position $\underline{\mathbf{0}} \% \mathrm{LB}$ to $\underline{\mathbf{7 0}} \%$ RB

48. Scour comments (eg. additional scour areas, local scouring process, etc.):

Scour is from $50 \mathrm{ft}$. US to $50 \mathrm{ft}$. DS.
49. Are there major confluences? $\mathbf{N}$
( $Y$ or if $N$ type ctrl-n $m c)$
50. How many? -
51. Confluence 1: Distance -
Confluence 2: Distance -
52. Enters on -
Enters on - ( $L B$ or $R B)$ ( $L B$ or $R B)$
53. Type- (1- perennial; 2- ephemeral)
Type - (1- perennial; 2- ephemeral)

54. Confluence comments (eg. confluence name):

NO MAJOR CONFLUENCES

\section{Under Bridge Channel Assessment}

55. Channel restraint (BF)? LB 2

56. Height (BF)
LB RB
$\mathbf{3 4 . 5}-$
58. Bank width (BF) -

59. Channel width $(\mathrm{Amb})$

(1- natural bank; 2- abutment; 3- artificial levee)

Bed and bank Material: 0- organics; 1- silt / clay, < 1/16mm; 2- sand, 1/16 - 2mm; 3- gravel, 2 - 64mm; 4- cobble, 64 - 256mm; 5- boulder, > 256mm; 6- bedrock; 7- manmade

Bank Erosion: 0- not evident; 1- light fluvial; 2- moderate fluvial; 3- heavy fluvial / mass wasting

64. Comments (bank material variation, minor inflows, protection extent, etc.):

3425

The left abutment and wingwalls are poured concrete. The right abutment is comprised of $3 \mathrm{ft}$. $x 3 \mathrm{ft}$. $x \mathbf{f t}$. concrete blocks stacked and overlapping. The right abutment wingwalls are placed stone at a slope varying from 70 degree to 45 degrees. The wingwall stones are $3 \mathrm{ft}$. to $4 \mathrm{ft}$. long and $1 \mathrm{ft}$. to $2 \mathrm{ft}$. thick. 
65. Debris and Ice Is there debris accumulation?

67. Debris Potential $\underline{3}$ ( 1- Low; 2- Moderate; 3- High)

69. Is there evidence of ice build-up? 2

70. Debris and Ice Comments:

2

Trees are scarred along both banks.
$(Y$ or $N)$ 66. Where? $\mathbf{Y}$

68. Capture Efficiency 2

(1- Upstream; 2- At bridge; 3-Both)

Ice Blockage Potential $\underline{\mathbf{Y}}$
(1-Low; 2- Moderate; 3- High)

(1-Low; 2- Moderate; 3- High)

\begin{tabular}{|l|c|c|c|c|c|c|c|c|}
\hline Abutments & $\begin{array}{c}\text { 71. Attack } \\
\angle \text { (BF) }\end{array}$ & $\begin{array}{c}72 \text {. Slope } \angle \\
\text { (Qmax) }\end{array}$ & $\begin{array}{c}\text { 73. Toe } \\
\text { loc. (BF) }\end{array}$ & $\begin{array}{c}\text { 74. Scour } \\
\text { Condition }\end{array}$ & $\begin{array}{c}75 . \text { Scour } \\
\text { depth }\end{array}$ & $\begin{array}{c}\text { 76. Exposure } \\
\text { depth }\end{array}$ & 77. Material & 78. Length \\
\hline LABUT & & $\mathbf{1 0}$ & $\mathbf{7 5}$ & $\mathbf{2}$ & $\mathbf{3}$ & $\mathbf{1 . 8}$ & $\mathbf{0 . 7}$ & $\mathbf{9 0 . 0}$ \\
\hline RABUT & $\mathbf{1}$ & - & $\mathbf{8 0}$ & & & $\mathbf{2}$ & $\mathbf{0}$ & $\mathbf{3 0 . 0}$ \\
\hline
\end{tabular}

Pushed: $L B$ or RB

Toe Location (Loc.): 0- even, 1- set back, 2- protrudes

Scour cond.: 0- not evident; 1- evident (comment); 2- footing exposed; 3-undermined footing; 4- piling exposed; 5- settled; 6- failed

Materials: 1- Concrete; 2- Stone masonry or drywall; 3- steel or metal; 4- wood

79. Abutment comments (eg. undermined penetration, unusual scour processes, debris, etc.):

-

1

The DS end of the left abutment and wingwall are undermined. The maximum penetration is $0.8 \mathrm{ft}$. The left abutment is a poured concrete wall. The undermined base is on top of boulders and the undermining is where one stone is missing. The right abutment is stacked concrete blocks capped with poured concrete to form the bridge seat.

76. The exposure depth along the LABUT refers to the undermined depth from the bottom of the concrete wall to the streambed.

80. Wingwalls: $\begin{array}{llll} & & & \\ \text { Exist? Material? } & \text { Scour } & \text { Scour Exposure } & \text { Angle? Length? } \\ & \text { Condition? depth? depth? } & & \end{array}$

USLWW:

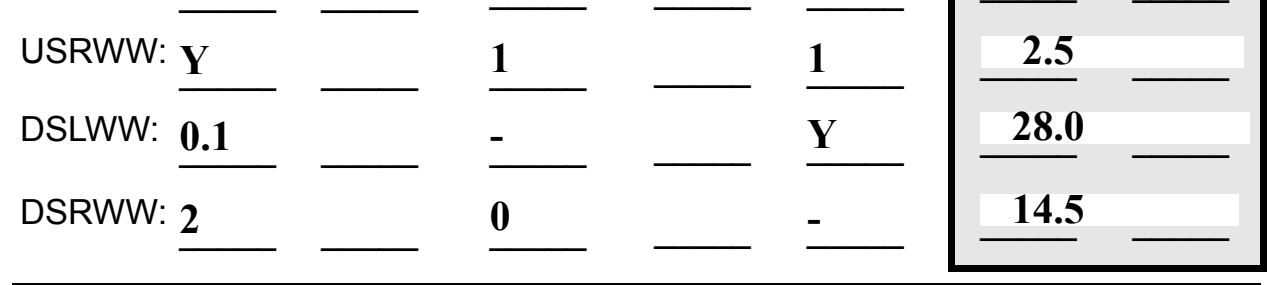

Wingwall materials: 1- Concrete; 2- Stone masonry or drywall; 3- steel or metal; 4- wood

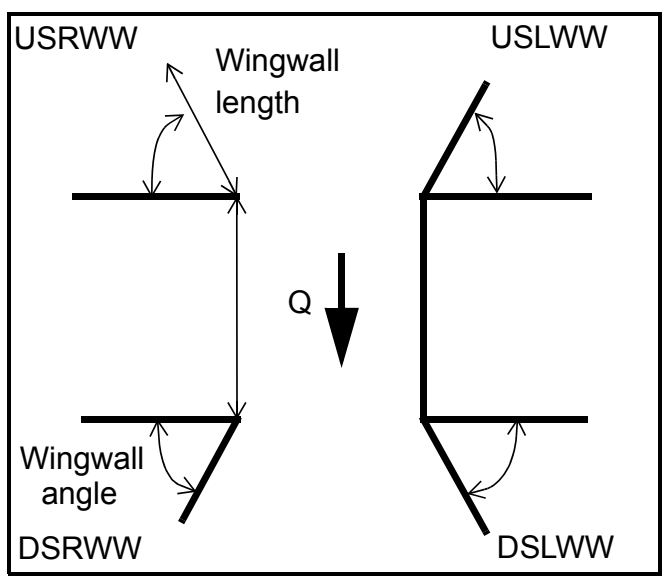

82. Bank / Bridge Protection:

\begin{tabular}{|l|l|l|l|l|l|l|c|c|}
\hline Location & USLWW & USRWW & LABUT & RABUT & LB & RB & DSLWW & DSRWW \\
\hline Type & - & $\mathbf{3}$ & $\mathbf{Y}$ & - & - & - & - & $\mathbf{1}$ \\
\hline Condition & $\mathbf{Y}$ & $\mathbf{1 . 7 5}$ & $\mathbf{2}$ & - & - & - & - & $\mathbf{1}$ \\
\hline Extent & $\mathbf{1}$ & $\mathbf{0 . 7}$ & $\mathbf{0}$ & $\mathbf{0}$ & $\mathbf{0}$ & $\mathbf{0}$ & $\mathbf{3}$ & - \\
\hline
\end{tabular}

Bank / Bridge protection types: 0- absent; 1- < 12 inches; 2- < 36 inches; 3- < 48 inches; 4- < 60 inches; 
83. Wingwall and protection comments (eg. undermined penetration, unusual scour processes, etc.):

$-$

$-$

$-$

$-$

0

-

0

0

\section{Piers:}

84. Are there piers? Th (Y or if $N$ type ctrl-n pr)

\begin{tabular}{|l|l|l|l|l|l|l|l|}
\hline \multirow{2}{*}{$\begin{array}{l}85 . \\
\text { Pier no. }\end{array}$} & \multicolumn{3}{|c|}{ width (w) feet } & \multicolumn{3}{c|}{ elevation (e) feet } \\
\cline { 2 - 8 } & w1 & w2 & w3 & e@w1 & e@w2 & e@w3 \\
\hline Pier 1 & & $\mathbf{6 . 5}$ & & $\mathbf{2 0 . 0}$ & $\mathbf{7 0 . 0}$ & $\mathbf{1 4 . 0}$ \\
\hline Pier 2 & & $\mathbf{7 . 5}$ & $\mathbf{7 . 5}$ & $\mathbf{5 0 . 0}$ & $\mathbf{9 0 . 0}$ & - \\
\hline Pier 3 & - & - & - & - & - & - \\
\hline Pier 4 & - & - & - & - & - & - \\
\hline
\end{tabular}

\begin{tabular}{|l|l|l|l|l|}
\hline Level 1 Pier Descr. & \multicolumn{1}{|c|}{1} & \multicolumn{1}{|c|}{2} & \multicolumn{1}{|c|}{3} & \multicolumn{1}{|c|}{4} \\
\hline 86. Location (BF) & ere is & left & their & \\
\hline 87. Type & nat- & wing & base & N \\
\hline 88. Material & ural & walls & stone & - \\
\hline 89. Shape & pro- & - & s. & - \\
\hline 90. Inclined? & tec- & The & & - \\
\hline 91. Attack $\angle$ (BF) & tion & right & & - \\
\hline 92. Pushed & alon & wing & & - \\
\hline 93. Length (feet) & - & - & - & - \\
\hline 94. \# of piles & g the & walls & & - \\
\hline 95. Cross-members & left & are & & - \\
\hline 96. Scour Condition & abut & pro- & & - \\
\hline 97. Scour depth & ment & tecte & & - \\
\hline 98. Exposure depth & and & d by & & - \\
\hline
\end{tabular}

LFP, LTB, LB, MCL, MCM, MCR, RB, RTB, RFP

1- Solid pier, 2-column, 3- bent

1-Wood; 2-concrete; 3- metal; 4- stone

1- Round; 2- Square; 3- Pointed

Y-yes; $N$ - no

$L B$ or $R B$

0- none; 1- laterals; 2- diagonals; 3- both

0- not evident; 1- evident (comment);

2- footing exposed; 3- piling exposed;

4- undermined footing; 5- settled; 6-failed 
99. Pier comments (eg. undermined penetration, protection and protection extent, unusual scour processes, etc.):

-
-
-
-
-
-
-
-
-
-

100.

\section{E. Downstream Channel Assessment}

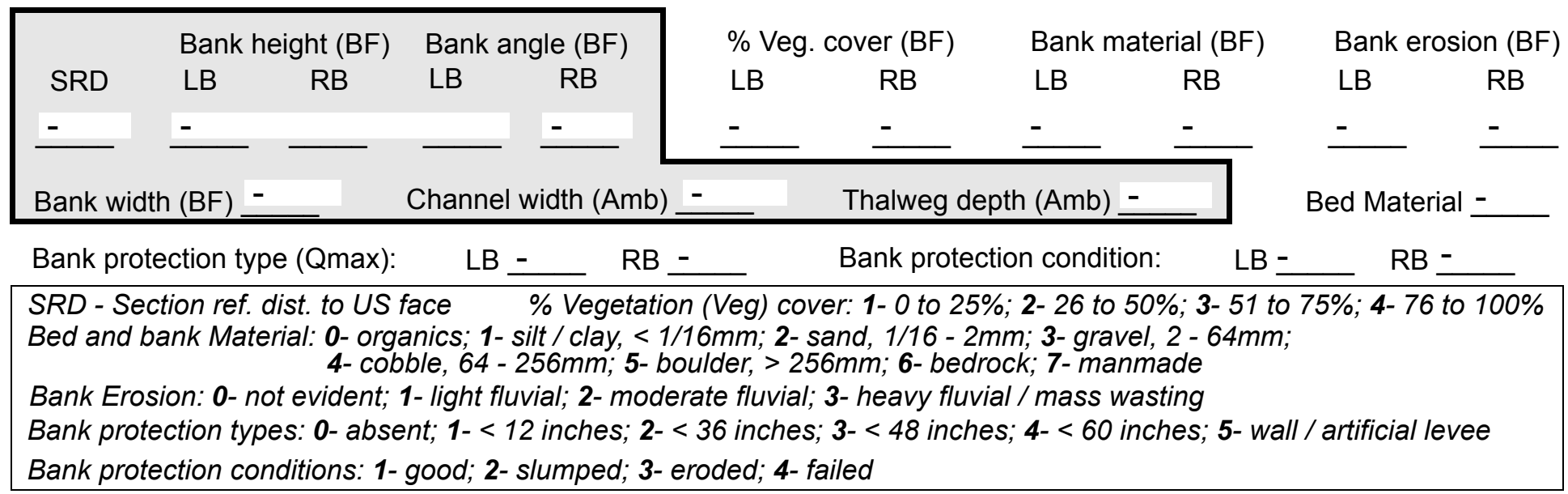

Comments (eg. bank material variation, minor inflows, protection extent, etc.):

-
-
-
-
-
-
-
-
-
-
-
-
-
-
-

101. Is a drop structure present? _ ( $Y$ or $N$, if $N$ type ctrl-n ds) 102. Distance: ___ feet 103. Drop: __ feet 104. Structure material: ___ (1- steel sheet pile; 2- wood pile; 3- concrete; 4- other) 105. Drop structure comments (eg. downstream scour depth):

NO PIERS 
Point bar extent: feet $\underline{1}$

(US, UB, DS) to 4 feet $\underline{453}$ (US, UB, DS) positioned $\underline{453}$

\section{Material: $\mathbf{2}$}

Point or side bar comments (Circle Point or Side; note additional bars, material variation, status, etc.):

\section{5}

2

2

1

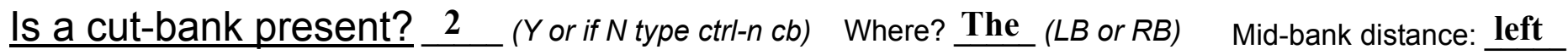
Cut bank extent: bank feet pro (US, UB, DS) to tec- feet tio (US, UB, DS)

Bank damage: $\mathbf{n}$ is (1- eroded and/or creep; 2- slip failure; 3- block failure)

Cut bank comments (eg. additional cut banks, protection condition, etc.):

from the end of the wingwall at $18 \mathrm{ft}$ DS to $115 \mathrm{ft}$ DS. The right bank protection is slumped and extends from end of the wingwall at $8 \mathrm{ft}$ DS to $25 \mathrm{ft}$ DS.

Is channel scour present? ( $Y$ or if $N$ type ctrl-n $c s)$

Mid-scour distance:

Scour dimensions: Length Width Depth:

Positioned $\%$ LB to $\%$ RB

Scour comments (eg. additional scour areas, local scouring process, etc.):

Are there major confluences? $\mathbf{N}$ ( $Y$ or if $N$ type ctrl-n $m c)$ Confluence 1: Distance NO Confluence 2: Distance $\underline{\underline{\text { STR }}}$ Enters on $\underline{\mathbf{D R}}$ (LB or RB) Enters on $\underline{\mathbf{U C}}$ (LB or RB) Confluence comments (eg. confluence name):

RE

\section{F. Geomorphic Channel Assessment}

107. Stage of reach evolution
1- Constructed

2- Stable

3- Aggraded

4- Degraded

5- Laterally unstable

6- Vertically and laterally unstable 
108. Evolution comments (Channel evolution not considering bridge effects; See HEC-20, Figure 1 for geomorphic descriptors):

Y
$\mathbf{5 0}$
$\mathbf{5}$
$\mathbf{2 8}$
DS
$\mathbf{9 0}$
DS
90
100
453




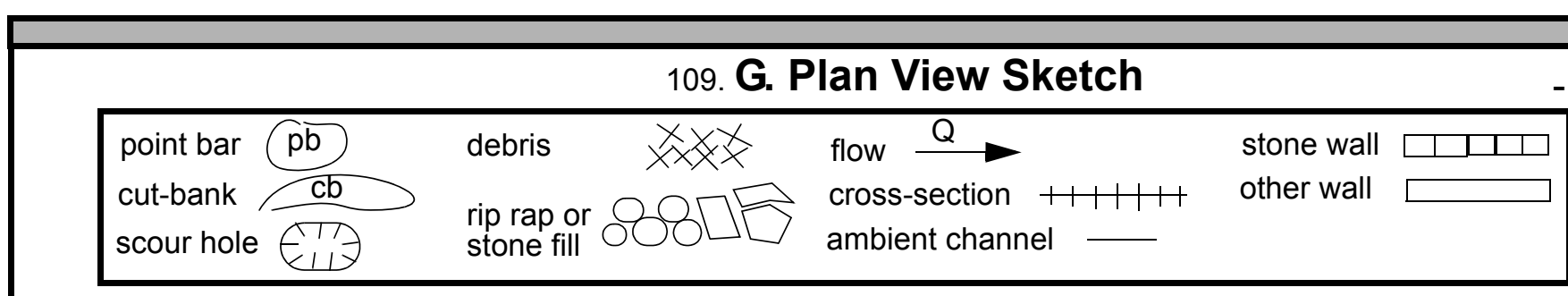

Po rip rap or
stone fill stone fill cross-section $\mathrm{H} \mathrm{H} \mid \mathrm{H}$ ambient channel other wall 
APPENDIX F:

SCOUR COMPUTATIONS 
SCOUR COMPUTATIONS

\begin{tabular}{|c|c|c|c|}
\hline Structure Number: CHESTH00090063 & & Town : & Chester \\
\hline Road Number: & & County: & Windsor \\
\hline Stream: Williams River & & & \\
\hline Initials RHF & Checked: & SAO & \\
\hline Analysis of contraction scour, live & bed or $\mathrm{c}$ ] & Lear wate & \\
\hline $\begin{array}{l}\text { Critical Velocity of Bed Material } \\
\mathrm{VC}=11.21 * \mathrm{Y}^{\wedge} 0.1667 * \mathrm{D} 50^{\wedge} 0.33 \text { with } \mathrm{S}\end{array}$ & $\begin{array}{l}\text { converted } \\
=2.65\end{array}$ & to Engl: & sh units) \\
\hline (Richardson and others, 1995, p. 28 & eq. 16$)$ & & \\
\hline Approach Section & & & \\
\hline Characteristic & $100 \mathrm{yr}$ & 500 yr & other $Q$ \\
\hline Total discharge, cfs & 5210 & 7640 & 2280 \\
\hline Main Channel Area, ft2 & 512 & 562 & 379 \\
\hline Left overbank area, ft2 & 6 & 28 & 0 \\
\hline Right overbank area, ft2 & 932 & 1142 & 361 \\
\hline Top width main channel, ft & 60 & 60 & 55 \\
\hline Top width L overbank, ft & 17 & 36 & 0 \\
\hline Top width $\mathrm{R}$ overbank, ft & 253 & 255 & 248 \\
\hline D50 of channel, ft & 0.1892 & 0.1892 & 0.1892 \\
\hline D50 left overbank, ft & -- & -- & -- \\
\hline D50 right overbank, ft & -- & -- & -- \\
\hline Y1, average depth, $M C$, ft & 8.5 & 9.4 & 6.9 \\
\hline y1, average depth, LOB, ft & 0.4 & 0.8 & $\mathrm{ERR}$ \\
\hline $\mathrm{Y}^{1}$, average depth, $\mathrm{ROB}, \mathrm{ft}$ & 3.7 & 4.5 & 1.5 \\
\hline Total conveyance, approach & 171143 & 224201 & 64863 \\
\hline Conveyance, main channel & 67710 & 79066 & 43233 \\
\hline Conveyance, LOB & 119 & 818 & 0 \\
\hline Conveyance, ROB & 103314 & 144317 & 21630 \\
\hline Percent discrepancy, conveyance & 0.0000 & 0.0000 & 0.0000 \\
\hline Qm, discharge, MC, cfs & 2061.3 & 2694.3 & 1519.7 \\
\hline Q1, discharge, LOB, Cfs & 3.6 & 27.9 & 0.0 \\
\hline Qr, discharge, ROB, cfs & 3145.1 & 4917.8 & 760.3 \\
\hline Vm, mean velocity $M C$, ft/s & 4.0 & 4.8 & 4.0 \\
\hline Vl, mean velocity, LOB, ft/s & 0.6 & 1.0 & ERR \\
\hline Vr, mean velocity, ROB, ft/s & 3.4 & 4.3 & 2.1 \\
\hline Vc-m, crit. velocity, $\mathrm{MC}$, ft/s & 9.2 & 9.3 & 8.9 \\
\hline Vc-l, crit. velocity, LOB, ft/s & $\mathrm{ERR}$ & ERR & ERR \\
\hline Vc-r, crit. velocity, ROB, ft/s & ERR & ERR & ERR \\
\hline Results & & & \\
\hline Live-bed(1) or Clear-Water(0) Contr & action Sc & our? & \\
\hline Main Channel & 0 & 0 & 0 \\
\hline Left Overbank & $\mathrm{N} / \mathrm{A}$ & $\mathrm{N} / \mathrm{A}$ & $\mathrm{N} / \mathrm{A}$ \\
\hline Right Overbank & $\mathrm{N} / \mathrm{A}$ & $\mathrm{N} / \mathrm{A}$ & $\mathrm{N} / \mathrm{A}$ \\
\hline
\end{tabular}

ARMORING 


$\begin{array}{llll}\text { D90 } & 0.5172 & 0.5172 & 0.5172 \\ \text { D95 } & 0.6544 & 0.6544 & 0.6544 \\ \text { Critical grain size,Dc, ft } & 0.2558 & 0.2707 & 0.2860 \\ \text { Decimal-percent coarser than Dc } & 0.3333 & 0.3033 & 0.2741 \\ \text { Depth to armoring,ft } & 1.54 & 1.87 & 2.27\end{array}$

Clear water Contraction Scour in MAIN CHANNEL

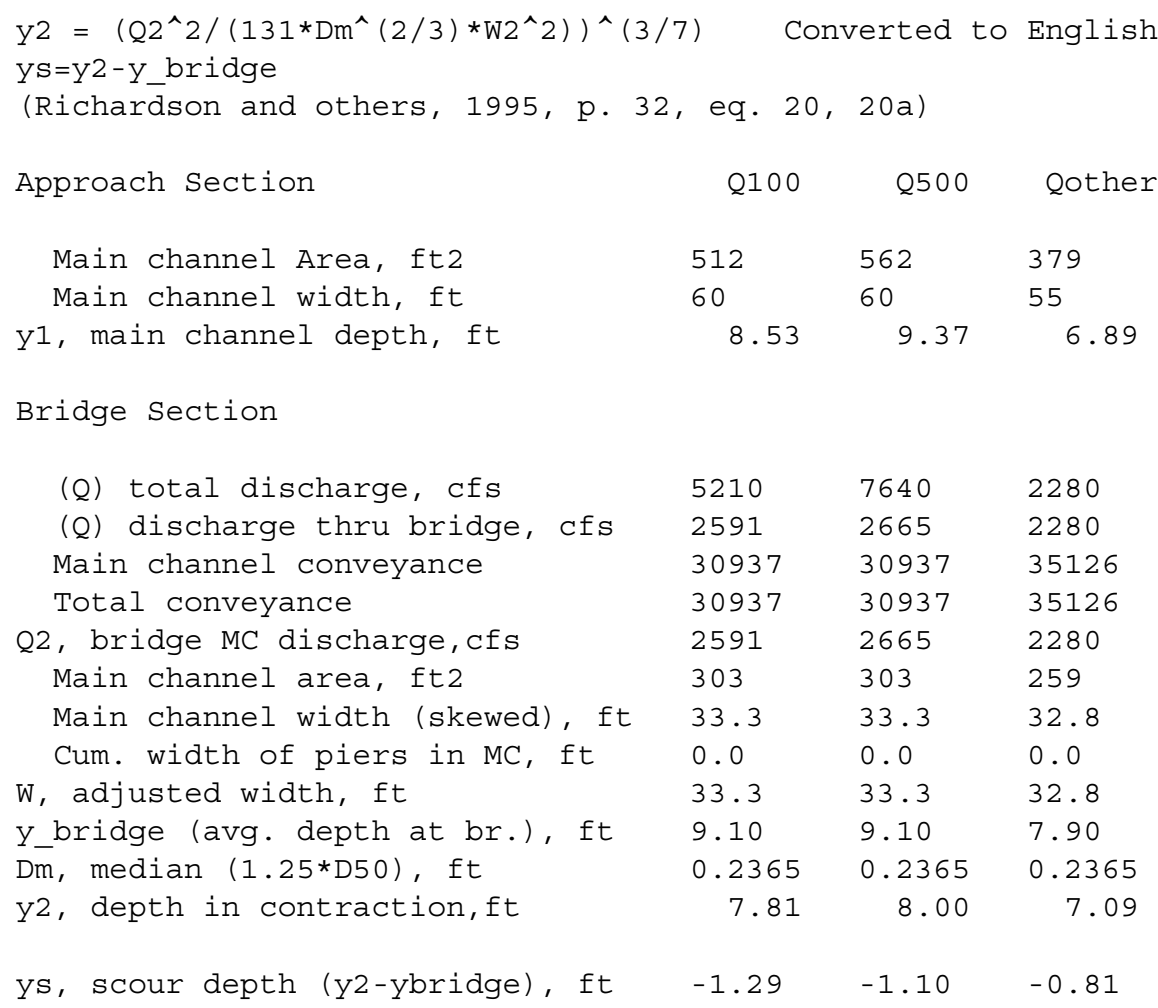

Pressure flow Scour (contraction scour for orifice flow conditions)

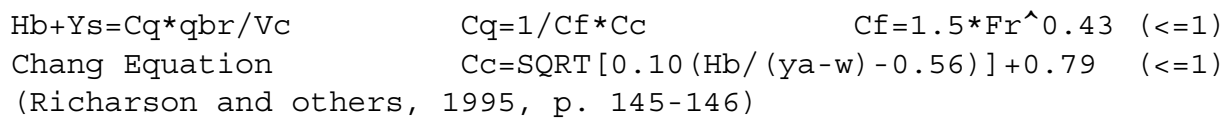

$\begin{array}{llll}\text { Q, total, cfs } & \text { Q100 } & \text { Q500 } & \text { OtherQ } \\ \text { Q, thru bridge, cfs } & 5210 & 7640 & 2280 \\ \text { Total Conveyance, bridge } & 2591 & 2665 & 2280 \\ \text { Main channel(MC) conveyance, bridge } & 30937 & 30937 & 35126 \\ \text { Q, thru bridge MC, cfs } & 2591 & 2665 & 2280 \\ \text { Vc, critical velocity, ft/s } & 9.20 & 9.34 & 8.88 \\ \text { Vc, critical velocity, m/s } & 2.80 & 2.85 & 2.71 \\ \text { Main channel width (skewed), ft } & 33.3 & 33.3 & 32.8 \\ \text { Cum. width of piers in MC, ft } & 0.0 & 0.0 & 0.0 \\ \text { W, adjusted width, ft } & 33.3 & 33.3 & 32.8 \\ \text { qbr, unit discharge, ft2/s } & 77.8 & 80.0 & 69.5 \\ \text { qbr, unit discharge, m2/s } & 7.2 & 7.4 & 6.5\end{array}$




$\begin{array}{llll}\text { Area of full opening, ft2 } & 303.0 & 303.0 & 259.0 \\ \text { Hb, depth of full opening, ft } & 9.10 & 9.10 & 7.90 \\ \text { Hb, depth of full opening, m } & 2.77 & 2.77 & 2.41 \\ \text { Fr, Froude number, bridge MC } & 0.50 & 0.51 & 0 \\ \text { Cf, Fr correction factor (<=1.0) } & 1.00 & 1.00 & 0.00 \\ \text { Elevation of Low Steel, ft } & 489.05 & 489.05 & 0 \\ \text { Elevation of Bed, ft } & 479.95 & 479.95 & -7.90 \\ \text { Elevation of Approach, ft } & 491.26 & 492.09 & 0 \\ \text { Friction loss, approach, ft } & 0.12 & 0.18 & 0 \\ \text { Elevation of WS immediately US, ft } & 491.14 & 491.91 & 0.00 \\ \text { ya, depth immediately US, ft } & 11.19 & 11.96 & 7.90 \\ \text { ya, depth immediately US, m } & 3.41 & 3.64 & 2.41 \\ \text { Mean elevation of deck, ft } & 491.53 & 491.53 & 0 \\ \text { w, depth of overflow, ft (>=0) } & 0.00 & 0.38 & 0.00 \\ \text { Cc, vert contrac correction (<=1.0) } & 0.95 & 0.94 & 1.00 \\ \text { Ys, depth of scour, ft } & -0.19 & 0.01 & \mathrm{~N} / \mathrm{A}\end{array}$

Abutment Scour

Froehlich's Abutment Scour

$\mathrm{Ys} / \mathrm{Y} 1=2.27 * \mathrm{~K} 1 * \mathrm{~K} 2 *\left(\mathrm{a}^{\prime} / \mathrm{Y} 1\right)^{\wedge} 0.43 * \mathrm{Fr} 1^{\wedge} 0.61+1$

(Richardson and others, 1995, p. 48, eq. 28)

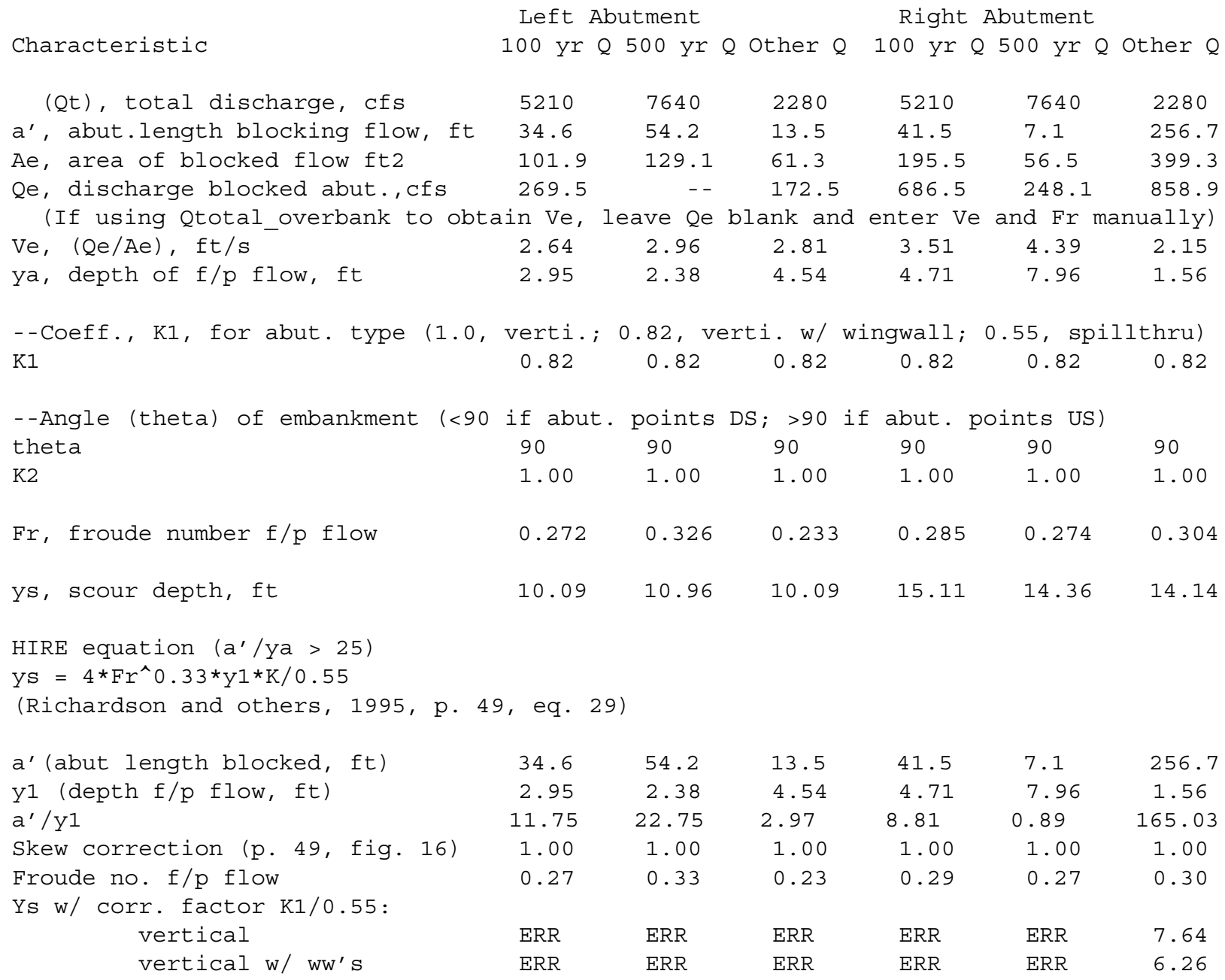




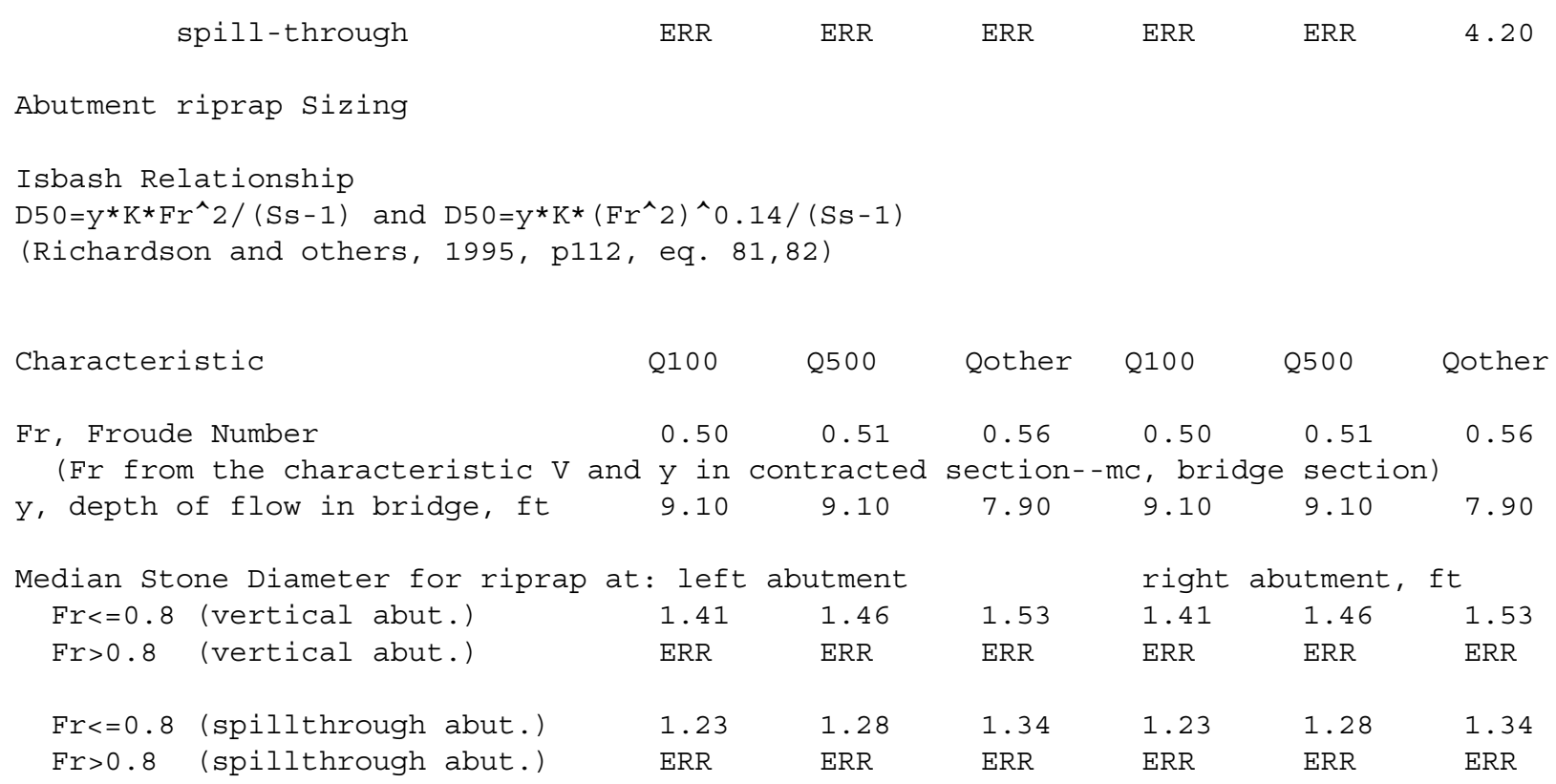

